\title{
SOEP
}

SOEPpapers

on Multidisciplinary Panel Data Research

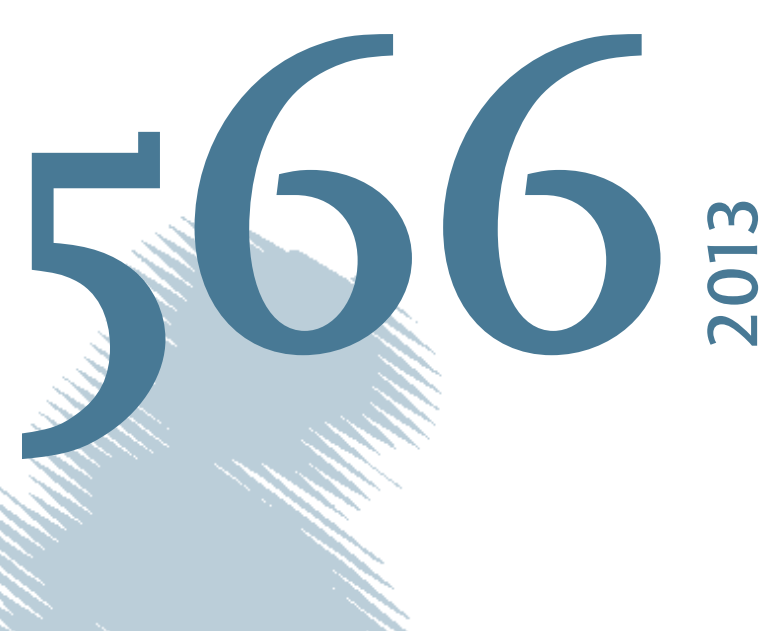

\section{Law and Social Capital: Evidence from the Code Napoleon in Germany}




\section{SOEPpapers on Multidisciplinary Panel Data Research}

at DIW Berlin

This series presents research findings based either directly on data from the German SocioEconomic Panel Study (SOEP) or using SOEP data as part of an internationally comparable data set (e.g. CNEF, ECHP, LIS, LWS, CHER/PACO). SOEP is a truly multidisciplinary household panel study covering a wide range of social and behavioral sciences: economics, sociology, psychology, survey methodology, econometrics and applied statistics, educational science, political science, public health, behavioral genetics, demography, geography, and sport science.

The decision to publish a submission in SOEPpapers is made by a board of editors chosen by the DIW Berlin to represent the wide range of disciplines covered by SOEP. There is no external referee process and papers are either accepted or rejected without revision. Papers appear in this series as works in progress and may also appear elsewhere. They often represent preliminary studies and are circulated to encourage discussion. Citation of such a paper should account for its provisional character. A revised version may be requested from the author directly.

Any opinions expressed in this series are those of the author(s) and not those of DIW Berlin. Research disseminated by DIW Berlin may include views on public policy issues, but the institute itself takes no institutional policy positions.

The SOEPpapers are available at

http://www.diw.de/soeppapers

\section{Editors:}

Jürgen Schupp (Sociology)

Gert G. Wagner (Social Sciences, Vice Dean DIW Graduate Center)

Conchita D'Ambrosio (Public Economics)

Denis Gerstorf (Psychology, DIW Research Director)

Elke Holst (Gender Studies, DIW Research Director)

Frauke Kreuter (Survey Methodology, DIW Research Professor)

Martin Kroh (Political Science and Survey Methodology)

Frieder R. Lang (Psychology, DIW Research Professor)

Henning Lohmann (Sociology, DIW Research Professor)

Jörg-Peter Schräpler (Survey Methodology, DIW Research Professor)

Thomas Siedler (Empirical Economics)

C. Katharina Spieß (Empirical Economics and Educational Science)

ISSN: 1864-6689 (online)

German Socio-Economic Panel Study (SOEP)

DIW Berlin

Mohrenstrasse 58

10117 Berlin, Germany

Contact: Uta Rahmann | soeppapers@diw.de 


\title{
LAW AND Social CAPITAL: EVIDENCE FROM THE CODE NAPOLEON IN GERMANY*
}

\author{
Johannes C. Buggle ${ }^{\dagger}$ \\ Sciences Po, Department of Economics
}

First version: May 22, 2012

This version: July 2, 2013

\begin{abstract}
Do legal institutions affect norms of cooperation? Using the introduction of the Code Napoleon during the Napoleonic Wars in Germany as a historical experiment, I show that a positive shock to the quality of legal institutions can increase social-capital long-lastingly. I find that individuals living in regions where the Code Napoleon was used display higher levels of interpersonal trust in the data of the German Socio-Economic Panel (SOEP). This result holds true conditional on past development levels, as well as in a less heterogeneous border sample, separating regions that applied the Code Napoleon from those that did not. Artificially moving the border and comparing regional pre-treatment characteristics support the interpretation of a causal treatment effect. In addition, I show immediate effects of the Code Civil on novel measures of 19th century social capital. The analysis of historical employment data furthermore suggests economic cooperation to be a potential mechanism for the relationship between legal institutions and social capital.
\end{abstract}

Keywords: Institutions, Long-Term Persistence, Social Capital.

JEL-Classification: N43, O10, P48, Z10

*I am grateful to Yann Algan for his ongoing support and encouragement. I thank Francesco Amodio, Davide Cantoni, Pauline Grosjean, Marc Sangnier, Andrei Shleifer, Guido Tabellini, Joachim Voth and seminar participants at the FRESH Meeting London, the UPF Reading Group on Persistence, the Spring Meeting for Young Economists 2013, and Sciences Po for very helpful comments and discussions at different stages of this project. Valuable research assistance was provided by Ferdinand Lutz and Malte Syman. I wish further to thank the DIW Berlin for making the SOEP data available, as well as the GESIS Leibniz Institute for Social Sciences. All errors remain my own.

${ }^{\dagger}$ Contact: 28 Rue des Saints-Pères, 75007 Paris, e-mail: johannes.buggle@sciences-po.org. 


\section{INTRODUCTION}

Social capital levels across and within countries are highly correlated with the quality of past and contemporary institutions (Putnam, 1994; Tabellini, 2008 and Tabellini, 2010; Guiso, Sapienza, and Zingales, 2008a Algan and Cahuc, 2013). ${ }^{1}$ However, empirical findings of a causal impact of impartial enforcement institutions on norms of cooperation are almost non-existent. Identification is particularly difficult as initial cultural norms of a society starkly influence the shape of its institutions. In this paper I make use of a historical experiment during which a legal institution was imposed from outside to identify the persistent impact of law on social capital. This historical experiment, the introduction of the Code Napoleon in parts of 19th century Germany, constituted a dramatic positive shock to the quality of existing legal institutions. Centered around the most modern legal code at that time and establishing a third party enforcement institution with the principle of equality before the law, the Napoleonic institutions "encouraged the liberation of the individual from corporative bonds and the establishment of a civil society" (Fehrenbach, 2008). My findings, estimated on the micro-level within a country, show that regions that used the Napoleonic Civil Code throughout the 19th century display on average higher levels of social capital. ${ }^{2}$ This supports the description of the positive social effects of the Code Napoleon and its legacy persisting to the present day. ${ }^{3}$

My analysis contributes to the recently emerging literature emphasizing the weight of history and particularly historical institutions for current beliefs. ${ }^{4}$ However, it differs from the latter in two important dimensions. First, rather then applying a broad definition of institutions, this paper considers a specific type: the law. In line with recent theoretical models (e.g. Tabellini, 2008; Guiso, Sapienza, and Zingales, 2008b), I expect impartial legal enforcement institutions to affect trust as they promote individual cooperation with anonymous others. ${ }^{5}$ Initially, in a society characterized by weak law enforcement, social and

\footnotetext{
${ }^{1}$ In a cross-section of countries one can observe a strong positive association between the quality of the legal system and trust, as Figure 1 displays. Countries protecting individual property stronger and in which courts and judges are independent and impartial display higher levels of interpersonal trust. This does not merely mirror an income effect, since the positive association is robust to controlling for income and education (see Figure 2). It cannot be deduced, however, that there exists a causal link going from the quality of the legal system to interpersonal trust. It is equally likely, that countries, in which individuals trust each other to a higher extent, also have stronger preferences for protecting property and value more an impartial and independent jury.

${ }^{2}$ Throughout this paper I apply a broad definition of "social capital" encompassing different measures used in the literature, such as individual beliefs as well as outcome measures.

${ }^{3}$ The long-run consequences of the law for economic outcomes has been intensively documented by scholars researching different legal origins. See for example López-de-Silanes et al. (1998) and La Porta, López-de-Silanes, and Shleifer (2008).

${ }^{4}$ See Nunn (2012) for a comprehensive summary of the literature relating history and culture.

${ }^{5}$ In the Appendix I propose a simple model of the type suggested by Guiso, Sapienza, and Zingales (2008b), introducing a third stage in the trust game, in which a court enforces contracts. The model enables me to make the cooperation decision contingent on the quality of the enforcement institution. The model predicts, that increasing the quality of the law will lead to more investment and higher levels of cooperation. Institutions can overcome the "no-trust-no-trade" equilibrium.
} 
economic interaction are discouraged as individuals have high incentives to cheat. This contrasts with an environment where legal enforcement is strong, and individuals, risking punishment by the law, are incentivized to cooperate. In a nutshell, in the second state of the world trust will emerge as a by-product of cooperation experienced in economic and social interactions. ${ }^{6}$ The reason why shocks affecting trust can manifest itself until today, is that beliefs transmitted inter-generationally from parents to children incorporate experiences made in the past in different institutional environments. A second distinctive feature of this paper is that it analyzes a change in the quality of the law that has not been created by the individuals for which it applies, but that has been imposed from outside. In other words, compared to existing contributions correlating past institutions with current social capital, my identification strategy is based on a rare historical experiment characterized by an exogenous change in the legal quality. Such historical experiment creates furthermore an ideal setting for studying the effects of institutions on culture, as it accounts for the long-term dimension necessary for observing substantial changes in beliefs over time. This important time-dimension is usually absent when analyzing current legal reforms or in experimental designs.

The introduction of the Code Napoleon is characterized by a drastic movement from a weak of rule of law to impartial legal enforcement in parts of 19th century Germany. The Code improved enforcement by establishing establishing universal access to the law, commercial freedom and an impartial judicial system. Using micro data from the German Socio-Economic Panel (SOEP), I show that those regions in which the Code Napoleon was introduced display higher levels of social capital related attitudes today. I start by comparing all regions that have used the Code Civil in the 19th century to regions that did not apply it, taking the number of years the Code Civil was applied before 1900 as the treatment. ${ }^{7}$ Importantly, the positive association does not reflect simple differences in 19th century regional development levels. It is robust to condition on historical controls, such as measures for past urbanization rates.

While the results suggest an effect of the Code Civil on contemporaneous levels of trust, there exist alternative explanations that could account for the positive association observed. First, differences in the initial social structure in regions applying the Code Civil might drive the results, if, for example, regions with high initial social capital were more likely to be treated. ${ }^{8}$ In this case, rather than identifying a treatment effect, the estimation would just pick up a path dependency of initial conditions. One draw-

\footnotetext{
${ }^{6}$ Supporting cooperation is, however, not the only channel through which the law can influence social capital. Legal rules, e.g. the principle of equality, can potentially spread on a more direct way into the society and become moral norms over time.

${ }^{7}$ In 1900, a unified Civil Code was installed in all German provinces, the Bürgerliches Gesetzbuch.

${ }^{8}$ Indeed, my identification strategy requires the adoption of the Code Civil to be uncorrelated with initial social capital levels.
} 
back of the complete sample regressions is the comparison of heterogenous regions that undertook very different paths of socio-economic development even before the treatment. To reduce heterogeneity in the sample, I then compare only regions located at a maximal distance of $50 \mathrm{~km}$ to a border. This border separates those regions that kept the code for about 90 years from those in which the Code was either never introduced or dismissed in 1815, after the Congress of Vienna. The results confirm the findings from the complete sample analysis: Treated regions exhibit higher levels of trust in the SOEP data. This is remarkable, as one would expect - in the absence of any treatment - spatially closely located individuals to be relatively similar in their attitudes. Indeed, a falsification test confirms this presumption. When the border is moved artificially outwards to the North-East or inwards to the South-West and a placebo treatment constructed, individuals in placebo treated regions do not show significant differences in trust levels.

I try to dismiss further doubts about the independence of the treatment with pre-treatment regional characteristics by comparing regional pre-treatment means of a set of variables identified by the literature as historical determinants of current levels of social trust. Treated and untreated regions turn out to not differ significantly with respect to those dimensions.

Arguably, the period of Napoleonic occupation did not only alter the law. In addition, the administration, as well as the educational system were changed and old elites removed. My treatment variable, which acts like a regional fixed effect, might rather proxy for the legacy of those changes. While I cannot control quantitatively for all unobserved regional heterogeneity, those factors are likely of subordinate importance compared to the legacy of the Napoleonic Code Civil. This is for a simple reason: Unlike the other reforms Napoleon introduced, the Code Civil lasted even after the Napoleonic retreat in 1815 for several decades. While possible, it is not very probable, that the short run-reforms were the main driver of the long-run change in beliefs. Historical evidence I will present supports this interpretation. Moreover, the results hold true even within a the formal borders of the Prussian kingdom, in other words holding kingdom characteristics constant.

The second part of the paper aims at shedding light on a possible channel and the immediate effects of the Napoleonic institutions on cooperation in the 19th century. I first look at potential effects on economic cooperation, focusing on sectors in which people interact frequently in business relations and rely on trust and reciprocity, such as in trade, factory employment and craft. Indeed, treated regions show a higher fraction of the population working as traders, factory workers or as craftsmen. To further test, whether cooperation inside the work environment spilled over on cooperation outside the work-place, I 
gathered two different measures of 19th century social capital. First, I collected data on memberships in gymnast clubs (Turnvereine) and the per capita share of volunteer firemen in associated volunteer fire departments on the county level and find them to be positively associated with the treatment. Second, I make use of a panel dataset measuring the number of shooting associations (Schützenvereine), having been founded between 1700 and 1900 per county in the neighboring provinces Rhineland and Westphalia. The panel data allows me to run regression yielding, that the number of associations increased significantly faster in the second half of the 19th century in the treated province Rhineland compared to its neighbor Westphalia. As this paper is one of the rare papers using additionally social capital data from the 19th century, it allows to discuss briefly persistence in the last part of the paper. ${ }^{9}$

This paper relates and contributes to several strands of the literature broadly researching the effects of institutions, culture and its interrelation. The first strand emphasizes the "deep-roots" of social capital levels we observe today. It goes back to Putnam (1994), who argued that differences in social capital between the North and South of Italy can be explained by the institutions associated with free and independent medieval city states in the northern part of Italy. This hypothesis is empirically tested and proven to be valid by Guiso, Sapienza, and Zingales (2008a). In the same spirit, Tabellini (2010) finds in a sample of 69 European regions that past institutions in the 18th century measured by the constraints on the executive are highly correlated with trust levels today. While those contributions characterize past institutions broadly as democracy, my approach departs from this definition as it considers a legal enforcement institution, and thus contains a precise mechanism for the observed positive relationship between past institutions and beliefs. The paper closest in its methodology is Becker et al. (2011a), who research the persistent impact of living in the Habsburg Empire, a kingdom characterized by its efficient administration. Focusing on individuals living in an area within 200 kilometers of the Empire's former border, the authors find individuals living in its former territory today to show more trust in institutions. Apart from historical institutions, other historical shocks have been found to alter norms and beliefs of a societies' inhabitants long-lastingly. Examples include the African slave trade, (Nunn and Wantchekon, 2011) and the surveillance apparatus in the former Communist Germany (Jacob and Tyrell, 2010). ${ }^{10,11}$

\footnotetext{
${ }^{9}$ Further evidence for the persistence of a particular cultural attitude, antisemitism, in Germany has been described by Voigtländer and Voth (2012)

${ }^{10}$ Interesting in the context of this paper, Nunn and Wantchekon (2011) hypothesize, that the slave trade did not only deteriorate social capital, but also paved the way for expropriate governmental institutions and a lax rule of law. In particular, they identify the weak legal system to be an important factor of the persistence of mistrust in the affected regions. Unconstrained political leaders are not forced to act trustworthy, and people can misbehave without being held responsible. Hence societies are stuck in an equilibrium of distrust and bad institutions

${ }^{11}$ Aghion et al. (2010) provide further evidence for a potentially detrimental role of the state for trust in the case of extensive regulation.
} 
Several theoretical contributions have tried to explain the persistence of cultural norms that has been documented empirically. The seminal contribution was made by Bisin and Verdier (2001). In their model parents transmit cultural traits to their children taking into account their future expected payoff. Tabellini (2008) builds on this model, and studies the determinants of cooperation and the evolution of norms over time. In his model, an exogenous shock to the quality of the enforcement institution, that reduces the loss of being cheated in a prisoners dilemma game, increases the scope of cooperation. Tabellini further argues, that when individuals can choose institutions by participating in the political process, good institutions will be reinforced. Shocks to the quality of institutions in the past are amplified by their affect on culture. Not values, but beliefs are the dimension of social capital Guiso, Sapienza, and Zingales (2008b) model to be passed from parents to children in a framework of an overlapping generations model. The model gives a rationale why differences in social capital originating in history are still observable today. ${ }^{12}$

My paper is also related to contributions researching the short-term effects of punishment and contract enforcement on cooperative behavior (see for example Fehr and Gächter (2000) for experimental evidence; Fisman and Miguel (2007) for evidence from a field experiment). Most recently Cassar, d'Adda, and Grosjean (2012) gathered interesting evidence for a causal link from institutions to norms of cooperations from experiments conducted in Italy and Kosovo.

Finally, my findings add to the analysis of the economic consequences attributed to institutions in general (see for example Smith, 1776, Milgrom, North, and Weingast, 1990, De Long and Shleifer, 1993, Acemoglu, Johnson, and Robinson, 2001; La Porta, López-de-Silanes, and Shleifer, 2008; Cantoni and Yuchtman, 2012) and the Napoleonic institutions, as described in Acemoglu et al. (2011), in particular. ${ }^{13}$ A shortcoming of this fascinating literature describing strong and persistent links between institutions and aggregated development is the lack of a detailed understanding of the channels going from institutions to economic outcomes. The results presented here do not only reinforce the interpretation of a positive impact on cooperation and trade, but potentially provide one of the channels through which (exogenously imposed) institutions can be favorable for economic growth: individual norms of cooperation.

The paper is structured as follows. Section 2 gives a brief description of the historical context needed for the empirical part. Section 3 assesses the effects of the Napoleonic institutions on current social capital outcomes, both in a sample of complete Germany and in a border sample. Section 4 shows the effects

\footnotetext{
${ }^{12}$ Empirical evidence of the intergenerational transfer of values can be found in Dohmen et al. (2012).

${ }^{13}$ Another strand of the literature disputes the fundamental role of institutions for economic development. See for example Glaeser et al. (2004) for the debate on the importance of human capital versus institutions.
} 
on trade, industrialization and social capital in 19th century Prussia. Section 5 concludes with a note on institutions, social capital and growth.

\section{Historical BaCkgRound: The COde Civil In GERMANY}

\subsection{French Occupation and Institutional Reform}

At the time of the French Revolution in 1789, Germany was fragmented into more than 300 states (Grab, 2003 , p. 85) and its social organization characterized by feudal institutions privileging the nobility and the clergy, (Grab, 2003, p. 86). The entry into professions and economic activities was to a large extent controlled by guilds restricting economic freedom. Germany's legal system consisted of a plurality of legal norms that differed often from town to town even within the same political territory. ${ }^{14}$ Peasants did not enjoy equality before the law, as they were subject to different courts and laws then the nobility (Acemoglu et al., 2011). Written legal codes did not exist at the end of the 18th century, except for the Codex Maximilianeus Bavaricus Civilis in Bavaria and the Allgemeines Landrecht (ALR henceforth) in Prussia, both of which allowed and practiced commonly the Partimonialgerichtsbarkeit, the privilege of the landlords to administer the law.

The French influence started with the occupation, and in 1798 the annexation, of the Rhineland, the entire German part west of the Rhine. To defend the French Empire against Prussia, Napoleon subsequently invaded large parts of the current German territory and by 1812 controlled directly or indirectly most of it, with the exception of Prussia and Austria. ${ }^{15}$

With the French occupation the Code Civil was introduced in the Rhineland, the Bavarian Palatinate and the part of Hessen, left of the Rhine and remained from 1802 to 1900. In 1901, the first civil code for the entire unified Germany, the Bürgerliches Gesetzbuch, replaced it. In several other states that fell under direct control of the French Empire the Code was in place for only few years. This states include Westphalia (from 1810-1815), Brunswick (1808-18014), Province of Saxony (1808-1815), Hanover (1808-

\footnotetext{
${ }^{14}$ The legal norms were derived from roman and canon law, the law of the church, and together constituted the so called Common Law (Gemeines Recht), not to be confused with the British law system, which is also named common law. It was a mixture of customary law and traditions and was executed by local rulers, the church or judges appointed by them.

${ }^{15}$ The motives for occupying a particular region have been twofold, as Acemoglu et al. (2011) note accurately. First, in order to defend France against Prussia and Austria, the territories in-between the Empires were strategically important. Second, the French revolutionaries wanted to enlarge the territory of the Empire to its natural borders: the Rhine, the Atlantic Ocean and the Alps, (Doyle, 1990 p. 199). The revolutionary leader Danton proclaimed on January, 31st 1793: "The limits of France are marked out by nature. We shall reach them at their four points: the Ocean, at the Rhine, at the Alps, at the Pyrenees." (quoted in Doyle (1990, p. 200).
} 
1813) and Hesse-Kassel (1808-1814). In the indirectly controlled states of the Confederation of the Rhine, Napoleon "pushed for the adoption of the Code" (Arvind and Stirton, 2010). Of those states only Baden finally adopted the Code Civil in 1810, motivated by the fear of a potential Napoleonic influence and incorporated in a larger agenda of defensive modernization (Acemoglu et al., 2011).

Crucial for the continuation of the Napoleonic institutions after 1815 was the reallocation of previously occupied regions at the Congress of Vienna in 1815. As a result of the Congress, several of the old rulers regained their power, rolling back the Napoleonic institutions in regions such as Brunswick, Saxony, Hanover and Hesse-Kassel. Where territories were allocated to states that could not offer an alternative civil code, as in the case of the Bavarian Palatinate given to Bavaria, those territories were commonly allowed to keep the Code Napoleon (see Stein, 2004). Only in the case of Prussia that gained power over regions in the West of Germany, in particular the territories of Westphalia and the Rhineland, things were slightly different. While the Prussian rulers forced its new province of Westphalia to abandon the Code Napoleon and to apply the Prussian Civil Code, the ALR, the neighboring province Rhineland was allowed to keep the Napoleonic institutions (Stein, 2004). The Rhineland was in a special situation as it has been part of the French Empire and as such had been applying the Code Civil for a much longer time before 1815. The continuation of the Napoleonic institutions in this part was supported by "reformminded Prussian officials" that "played a crucial role in ensuring that [it] was not immediately swept aside", (Rowe, 2003, p. 281). Although the continuation was also favored by local elites, who came to acknowledge the value of the French institutions and who saw in the Code Civil a protection against arbitrary authority of the new unknown rulers from the East, (Rowe, 2003, p. 281), they were not in the position to decide. Importantly, the power to decide about the continuation of the Code Civil ultimately lay in the hands of the new autocratic rulers and was therefore independent of the population's opinion.

As a result, the Code Civil existed throughout the 19th century in the Rhineland (given to Prussia), consisting of the areas West to the Rhine river and small parts on the right bank of the Rhine, formerly belonging to the Duchy of Berg, the Bavarian Palatinate (given to Bavaria), the part left of the Rhine belonging to Hessen-Darmstadt, as well as Baden. ${ }^{16,17}$ Figure 3 pictures the distribution of civil law in Germany throughout the 19th century. Besides the regions using the Code Civil, most of the remaining German regions either sticked to common law or applied the Prussian ALR throughout the 19th century.

Figure 3 about here

\footnotetext{
${ }^{16}$ Table B.1 in the Appendix lists the number of years the Code Civil was in place per territory.

${ }^{17}$ In the Rhineland only the districts Essen, Duisburg, Muehlheim (Ruhr) did not keep it.
} 
Figure 4 shows the years the Code Civil was in place in a territory before 1900.

$$
\text { Figure } 4 \text { about here }
$$

The Code Civil altered the existing law in several dimensions, of which two stand out: First, it granted equality before the law to all men, removing any form of privileged treatment for nobilities in front of the court. This implied that the same rules applied to everyone, independent of income and status (Lyons, 1994, p. 95). This principle does clearly differentiate the Code Civil from all other legal sources at that time. Although the ALR also contained the principal of equality before the law, in practice it was not enforced. The Partimonialgerichtsbarkeit, the privilege of the landlords to administer the law, was still allowed and practiced commonly in Prussia and in the rest of Germany. Equal access to an impartial law increased law enforcement. It was furthermore fostered by the reformation of the entire judicial procedures and the installation of new courts of appeal, as well as commercial courts. ${ }^{18}$

Second, the Code Civil guaranteed property rights and commercial freedom, including a "modern conception of property ownership" (Lyons, 1994, p. 96). All individuals were granted absolute rights of ownership and starting a business only required a business license from the local city administration (Becker, 1985). Sperber (1992, p. 38) describes the civil liberties established by the Code Civil as having been exceptional in early 19th century Germany. While the institutional reforms also included the reformation of the administration and the removal of old elites, compared to the Code Civil those were of subordinate importance. As Rowe puts it, the "Napoleonic rule, far from making Rhinelanders used to authoritarianism, endowed them with a new set of institutions that blunted it. Chief amongst these was the law." (Rowe, 2003, p. 281)

\subsection{Social Consequences}

As a result of the Napoleonic occupation the entire social system that had been predominant for hundreds of years was reformed and altered almost over night, with the aim of a more equal society. As the historian Martin Lyons notes:

[...] the abolition of privilege also removed the social barriers which had prevented the bour-

\footnotetext{
${ }^{18}$ In the territories left of the Rhine for example, ordinary people were appointed as Justices of Peace (JP), being in charge of pre-trial settlements of minor cases. They were in particular appealed in labor conflicts in a more and more industrialized society (Haferkamp), settling disputes in the market about the quality of work between masters and manufacturers, as well as those between masters and journeymen or apprentices, who often broke contracts and left their masters on their own (Sperber, 1992 p. 55). "Courts would provide a remedy by ensuring the exact fulfillment of [...] contracts", writes Sperber (1992 p. 56) and refers to the manufacturing tribunals, which provided a form of "industrial mediation" between manufacturers, workers and journeymen (Sperber, 1992, p. 55)
} 
geoisie from buying land, and deterred the nobles from engaging in industry and commerce.

(Lyons, 1994, p. 235)

In particular in the Rhineland the transformation was drastic, from a region characterized before the Napoleonic occupation as a "particularly old-fashioned, pre-absolutistic, feudal system"19 (Nipperdey, 1983, p. 78), to being “well advanced socially to the rest of Germany"20, (Nipperdey, 1983, p. 78). This happened, because "the French law and his idea of a society made up of free and equal property owners have penetrated the civil movement"21, (Nipperdey, 1983, p. 79).

Thus, the Napoleonic reforms laid the foundation for a modern society, in which a greater share of the population was able to acquire property, to engage in trade and commerce, which was backed up by a strong centralized legal institution. Birth was not anymore decisive for social status, since "ownership of property in a free market" became the "main criterion for social stratification" (Sperber, 1992, p. 33). Comparing the Rhineland to the rest of Prussia, Sperber describes Prussia as a far less progressive kingdom, with social structures and institutions "too different from those [...] along the Rhine" (Sperber, 1992 , p. 38). While in the Rhenish territories, "the tone was set by the bourgeois elite of bankers, merchants, manufactures, rentiers, lawyers and notaries" (Sperber, 1992, p. 38), i.e. a large and important bourgeoisie and middle class, the nobility was still highly influential in Prussia. This enlarged access to the market and the participation of a greater share of the society resulted in more economic growth in the affected regions (Acemoglu et al., 2011).

\section{Estimating the Effect on Contemporaneous Social Capital}

This section estimates the impact of the Napoleonic institutions on survey data outcomes related to trust and cooperation in current day Germany. I start by analyzing the association between the Code Civil and current social trust in a sample of 16 historical territories covering almost the entire current Federal Republic. To remove heterogeneity in characteristics potentially affecting the outcome variables, I then restrict the sample to a border sample separating regions that applied the Code Civil for on average over 90 years from regions that applied it for only about 5 years. Next, I create a fictitious treatment by moving the border to further test the existence of a "true" treatment effect. To address the concern of a violation of the independence of the treatment with pre-treatment social capital levels, I finally compare mean

\footnotetext{
${ }^{19}$ Author's translation.

${ }^{20}$ Author's translation.

${ }^{21}$ Author's translation.
} 
differences between the treatment groups of pre-treatment characteristics mattering for social capital and discuss alternative explanations.

\subsection{Contemporaneous Data}

Measures for contemporaneous social capital levels in Germany are created by using survey data from the German Socio-Economic Panel (SOEP) (Wagner, Frick, and Schupp, 2007). The SOEP asked questions about personal attitudes in the years 2003 and 2008. I only make use of the 2003 wave, as it includes a richer set of control variables. The outcome variable I am primarily interested in is interpersonal trust. In the survey, respondents have to evaluate ("totally agree", "slightly agree", "disagree slightly", "totally disagree") the following three statements related to interpersonal trust: "On the whole one can trust people", "Nowadays one cannot rely on anyone", and "If one is dealing with strangers, it is better to be careful before one can trust them". I recode the variables on a scale from 1 to 4 , such that the highest value is assigned to the highest level of trust. The variable Trust is then computed as the average out of the individual scores for each question. To undertake robustness checks I also construct two additional variables measuring norms of cooperation. The SOEP asks respondents about the perceived behavior of others with respect to fairness: "Do you agree that most people... a) exploit you if they had the opportunity or b) would attempt to be fair towards you?", as well as with respect to helpfulness: "Would you say that for most of the time, people... a) attempt to be helpful? b) or only act in their own interests?". Out of those questions I construct two binary outcome variables, labeled Fair and Help, such that the value 1 indicates a higher level of perceived fairness, respectively willingness to help. As Guiso, Sapienza, and Zingales (2010) show for the WVS, answers from social value survey questions concerning trust reflect the beliefs of the sender about the trustworthiness of the receiver. This is perfectly relevant here in order to elicit the updating and persistence of beliefs following a exogenous legal change. As the treatment should only affect measures related to cooperative attitudes, I additionally construct a measure of the strength of family ties as a counterfactual. I use the frequency of family visits as a proxy for the importance of the family. Individuals with strong family ties are likely to visit their family members more often. The related question in the SOEP asks "Please indicate how often you take part in each activity: Visits to and from family members and relatives". The variable is measured on a 5 point scale, where 1 indicates "daily", 2 "at least once a week", 3 "at least once a month", 4 "seldom", 5 "never". That is a higher score of the variable Family indicates weaker family ties.

The geographical level up to which individual observations can be located regionally is the county level. 
This geographical level is equivalent to the NUTS 3 level of the Statistical Units of the European Union and includes more than 400 regions. ${ }^{22}$ To control for other influences of social capital I will include several individual control variables, such as the respondent's age and its square, dummy variables indicating the gender of the respondent and whether the respondent was unemployed in the last year or not, as well as the household income in the last month. To account for the legacy of the former Communist regime in Germany I add another dummy that takes on the value 1 if the respondent lived before 1990 in the former East of Germany. Education is controlled for using six different indicator variables for schooling and distinguishes between having no school degree at all, having attended a 9 year middle school (Hauptschule), a 10 year middle school (Realschule), a 12 year secondary school (Fachhochschulreife) or having obtained the highest secondary school degree after 13 years of school (Abitur). Furthermore, I control for five categories of religious affiliation which are protestant, catholic, any other Christian religion, a different religion that is not Christian or none religious affiliation at all. Since my focus of attention lies on the intergenerational transfer of individuals' beliefs from their ancestors that have lived in the particular historical territory many years ago, ideally I would like to consider only individuals for which I can identify the historical territory of their ancestors residence during the 19th century. Unfortunately, the SOEP data does not provide information about the location of ancestors. The second-best in order to reduce a possible bias caused by migration is to delete foreigners, that is non-German citizens as well as second generation immigrants, from the sample. These individuals most likely share a different culture, traditions and norms that are linked to their country of origin. ${ }^{23}$

\section{Table 1 about here}

The current location of each individual is matched with the 16 historical territories for which historical data is available, i.e. historical territories are matched to current districts. Historical borders match remarkably well with current district borders and cut only through very few districts. Current districts that straddle a historical border will be assigned to a historical region depending of the historical location of the districts current capital. As historical controls I include the territories urbanization rate in 1850 to control for mere historical income differences across territories, the initial urbanization rate and the share of protestants in 1800, the longitude and latitude of the territories' capital and its distance to Paris. The source for the historical data is Acemoglu et al. (2011). ${ }^{24}$ Table 1 provides summary statistics for

\footnotetext{
${ }^{22}$ Because of the confidentiality requirements of the data on this detailed regional level it was accessed via a remote access.

${ }^{23}$ Against the deletion of immigrants one could argue, that past institutions persisted and influenced beliefs and values of all citizens today. However, this is not the channel that is proposed here. In contrast, I argue that past institutions affected beliefs and values in the past, and these attitudes persisted until today. See also Algan and Cahuc (2010) for the correlation between trust of immigrants and trust in the home country.

${ }^{24}$ Table B.1 in the Appendix gives the territories included in the sample and the treatment.
} 
the individual data for both the complete and the border sample. After the deletion of immigrants and those territories, for which historical data is not available, more than 15000 individuals are observed and included in the complete sample.

\subsection{Complete Sample Analysis}

I will begin with estimating the effect of the Code Civil for current trust keeping a sample including all German regions.

The following model is regressed:

$$
Y_{i, d, h}=\alpha+\delta * \text { civil }_{h}+X_{i, d, h}^{\prime} * \beta+u_{i, d, h}
$$

where $Y_{i, d, h}$ measures one of the social capital related outcomes of individual i living in district d, belonging to historical territory h. civil $h$ measures the number of civil years in historical region $\mathrm{h}$ before the year 1900. The matrix $X_{i, d, h}$ contains a list of individual controls, specified above.

Table 2 about here

Results of the regressions are displayed in Table 2. Column (1) shows the basic correlation between the Code Civil and individual trust, only controlling for macro-region fixed effects for the four macro-regions north, south, east and west. The coefficient is positive, and significant on the $1 \%$ significant level. Thus, individual trust is increasing in the number of years the Code Civil was used. This finding is robust to using cooperation and fairness as outcome variables in columns (2) and (3). I then add individual controls (age, age sq., gender), economic controls (household income, unemployment dummy), 5 categories of educational attainment and 4 categories of religious denomination. As it is visible from column (4), the coefficient of the Code Civil treatment decreases slightly - both in its significance and magnitude. Having applied the Code Civil for one standard deviation of about 37 years increases trust by 0.015 in absolute terms, a 98 year treatment increases trust by on average 0.04 , or 8 percent of a standard deviation of trust. In column (7) I regress the same model but now using the proxy for family ties as dependent variable. Since the link proposed here goes from institutional quality to cooperation and not to other attitudes, such as attitudes towards family, I do not expect to find a significant correlation. Indeed, as column (7) shows, the coefficient of interest is positive, but not significant. Next, I control for historical determinants on the territory level. In particular, I include the urbanization rate and the share of protestants in 1800 , 
the urbanization rate in 1850, the longitude and latitude of the historical territory, and the distance of its capital to Paris. The share of protestants has been shown to be a good proxy for educational attainment (Becker and Woessmann, 2009) and protestantism goes along with values favorable for cooperation compared to catholicism (Alesina and La Ferrara, 2002; Tabellini, 2008). Controlling for past influences almost doubles the magnitude of the coefficient and increases its significance for all outcome variables, as shown in columns (8) to (10). Having applied the Code Civil for a standard deviation of 37 years goes along with 0.06 of a standard deviation higher level of trust, while 90 years go along with an increase of 0.17 of a standard deviation in trust. To put this magnitude in relation, switching from catholicism to protestantism increases individual trust on average by 0.006 of a standard deviation, being unemployed reduces trust by 0.22 of a standard deviation, while having lived in the former GDR reduces trust by a coefficient of 0.15 of a standard deviation in trust.

\subsection{Robustness of the Complete Sample}

I will perform additional regressions in the framework of the complete sample to show the robustness of the results in different sub-samples. Restricting the sample provides furthermore a possibility to mitigate possible endogeneity concerns related to the adoption of the Code Civil. In the first specification I will drop the historical territories Baden and Saxony, which choose to adopt the Code Civil - although this choice was severely constrained in the case of Baden. The finding of a positive, significant effect is robust to this specification, as column (1) in Table 3 show. Next, only regions are kept in the sample that either adopted the Code Civil through Napoleonic occupation, adopted it voluntarily or at least prepared its adoption, as the two members of the Confederation of the Rhine Bavaria and Hesse-Darmstadt, did. The idea is to compare places that almost got the Code Civil, with those having actually adopted it, removing regions from the sample that rejected the Code Civil completely and did not consider its application. ${ }^{25}$ Thus, the sample is characterized by a lower degree of heterogeneity in the adoption decision. I still find a positive, significant effect in column (2).

Table 3 about here

Going one step further, I consider only regions that adopted the Code Civil either voluntarily or prepared to adopt it. This leaves me with the regions Baden, Bavaria and Hesse-Darmstadt. All three regions where never directly occupied by Napoleon, but indirectly connected to the French Empire through the

\footnotetext{
${ }^{25}$ The classification of whether a region considered the Code's adoption is taken from Arvind and Stirton (2010)
} 
Confederation of the Rhine, and as such pushed by the French Emperor to adopt its institutions. As column (3) shows, Baden, the region that has actually adopted the Code Civil has significantly more trust today. The estimated coefficient in column (4) shows that there exists a positive relationship between the years of the Code Civil was in place and trust in a sample of regions that actually applied the Code Civil for at least some years. This indicates that it is not the pure adoption of the Code Civil, but the duration which matters for long-run changes in beliefs. Moreover, within a sample of regions that all were occupied by the French Army in column (5) I find the same positive relationship between having the duration of the Code Civil and trust today. While possibly all occupied regions experienced the same Napoleonic effects of the occupation, those in which the Code Civil was used after the Napoleonic retreat show higher trust today. Finally, within Prussia the positive association holds true (see column (6)), i.e. holding kingdom characteristics constant from 1815 on.

\subsection{Identification}

Up to this point this section has established a robust positive association between the application of an impartial legal enforcement institution in 19th century German regions and trust in different samples. Two explanations can potentially account for this finding: First, treated regions were characterized by higher levels of social capital before the treatment took place. In other words, the treatment was not distributed independently of the initial culture. In that case, the results from the estimation only picks up path dependencies reflecting pre-treatment differences. Second, regions started out with comparable levels of social capital and the Napoleonic treatment influenced social capital levels positively, i.e. there existed a causal effect.

In the following paragraphs I will show that the evidence from a border sample (3.5 and 3.6) and the comparison of pre-treatment characteristics (3.7) point overwhelmingly towards the second explanation, that is a true treatment effect. Treatment in this historical experiment contains the adoption and continuation of the Code Civil. The evaluation of the historical literature, as described above, suggests that the selection and occupation of the territories by the French Army was not driven by economic or cultural factors, but by geo-political motives. Equally important for the identification strategy is the question why regions that adopted the Code Civil did not continue its application after 1815. The historical sources give rise to the interpretation that the continuation largely depended on the outcome of the political bargain at the Congress of Vienna and the level of reform-mindedness of local autocratic rulers, most likely at conflict with the preferences and values of their citizens. 
However, the treatment arguably is spatially clustered, as regions close to France have been more likely to be treated. ${ }^{26}$ That implies that the complete sample specifications compare possibly heterogeneous regions, geographically as well as culturally. Comparing a region located at the Baltic Sea with a region in the South-West of Germany is problematic in several ways. Cultural differences might have been fundamental, in a sense that those regions started out with different levels of social capital in the early 19th century. Differences in local characteristics, such as of geographical nature, e.g. the access to the coast, and the paths of economic development undertaken are further potential influences of cooperation. I would therefore like to compare more homogeneous, that is more closely located, regions.

I therefore restrict the sample to a border sample of individuals living in regions within a $50 \mathrm{~km}$ corridor from the border, separating regions that applied the Code Civil for more than 90 years from those that applied in only few year. This sample thus reduces heterogeneity in fundamental pre-treatment characteristics, as closely located individuals can - in the absence of a treatment - be expected to express relatively similar norms and values.

The border sample has two further interesting features, as it first defines the treatment only for regions that adopted the Code Civil for a long time. If the institutional and legal reform had an effect on culture, a slowly moving and hard to change variable, it is more likely that the effect of the Code Civil needed several years to disperse. Indeed, Guiso, Sapienza, and Zingales (2008b) estimate, that a shock requires about 75 years ( 2 to 3 generations) to have a long-lasting effect on social capital. The timespan of the longest adoption of the Code in the sample, more than 90 years, fits very well to this estimation. Furthermore, the border specification allows to analyze effects within current Federal States. Being a federal republic, Germany has transferred some of its administrative duties to the sixteen federal states (Länder) that are, for example, in charge of the education system, but more relevant in this context the police and court system. It is possible that current differences in the functioning of local institutions influence social capital, and thus potentially bias the results.

\subsection{Border Effects}

The border sample analysis compares regions having applied the Code Civil on the East (left) side of the border with regions having used either common law or the ALR on the West (right) side of the border. On both sides of the border those regions are included in the border sample whose centroids have a maximal

\footnotetext{
${ }^{26}$ In the complete sample I partially account for this by controlling for the distance to Paris and measures for the longitude and latitude.
} 
GIS measured distance of $50 \mathrm{~km}$ to the border. Figure 5 displays the spatial distribution of the treatment.

\section{Figure 5 about here}

In contrast to the the complete sample analysis, it is more natural to define the treatment as a dummy variable that takes on the value 1 if the region is located on the left side of the border, and 0 otherwise. I will refer to the first group as the treated and the latter as the untreated. The treated group kept the Code Civil on average more than 90 years and thus significantly longer than the regions on the right of the border. Summary Statistics for the border sample are also displayed in Table 1 .

Table 4 about here

Table 4 shows the results of the regressions conducted. The first regression includes all border locations, even those located in Federal States without within state treatment variation. The coefficient of the treatment border controlling for individual controls is positive and significant on the 1 percent level. Individuals living in the treated regions, have on average a 0.04 higher level of trust. To be able to include Federal States fixed effects, I restrict the sample so that only federal states with within variation in the treatment remain. Consequently I keep only counties located in the territories Rhineland, Westphalia, Mark, Baden and Wuerttemberg. In column (2) an identical model as in column (1) is regressed, this time using the restricted sample. The results are comparable in magnitude, although with a coefficient of 0.05 a bit higher and significant on the 1 percent level. Column (3) to (4) show the robustness of this result using the other two social capital related questions as outcomes. Column (5) to (7) include controls for religion, education, economic controls as well as Federal States fixed effects that account for unobserved heterogeneity on the federal state level. The treatment variable stays positive and significant for all outcomes. The magnitude of the effect for trust $(0.049)$ is larger then the influence of the personal controls and religion, but smaller then the effect of education and economic controls. Having applied the Code Civil results in about 0.1 of a standard deviation higher trust today. When the same model is regressed using family values as a counterfactual attitude, I do not find a significant difference between treated and untreated regions. This again supports the peculiar impact of the quality of institutions on cooperation. In column (9), only the two historical regions Rhineland and Westphalia are compared, thus excluding Baden, and Wuerttemberg. The exclusion follows the same reasoning as in the complete sample analysis, as Baden, which did not directly adopt the Code Civil through French occupation, is dropped. It is a particularly interesting specification as it allows to identify within Prussia effects, as both, Rhineland and Westphalia were part of Prussia after 1815. In other words, holding all other 
common Prussian characteristics constant, the estimation produces a positive and significant coefficient. Finally, column (10) includes urbanization in 1850 as a control. The result is robust to include alternative historical controls, one by one, as shown in Table 5. Including those controls leads the coefficient to decrease slightly, as well as its significance. The weaker results can be attributed to the limited regional variation in this specification with only 5 historical territories.

\section{Table 5 about here}

I find very similar results in a standard spatial regression discontinuity design, controlling for the distance, its square and distance interacted with the treatment variable, as shown in Table 6 .

Table 6 about here

\subsection{Moving the Border}

In this subsection I conduct a falsification exercise similar to Becker et al. (2011a). The goal is to support the identification of causal link, i.e. to show that the treatment effect found in the previous subsection does not reflect a general West-East pattern, but a genuine treatment effect. To generate a false treatment the border is moved twice. The first time it is moved outwards, that is to the North-East. This allows to generate a placebo treatment comparing individuals living in regions unaffected by the true treatment on both sides of the border. Then the border is moved inwards, that is to the South-West, so to compare regions that have been treated on each side of the border. In both cases one would expect to find a nonsignificant treatment effect. For the outwards shift because there did not exist a true long-term Napoleonic treatment. For the inward shift because actually treated regions should be similar with respect to trust levels. I construct two new borderlines, each being the joint outline of the regions included in the original border sample. For the inward shift this is the common outline of the treated, for the outward shift this is the common outline of the untreated group. I then follow the procedure above and include regions that are located within a $50 \mathrm{~km}$ band on each side of the border, only keeping federal states having within state variation in the placebo treatment. Regions on the left to the border are considered as having been treated by an improvement in the law enforcement. See Figure 6 for a graphical representation of the regions included in the different samples.

Figure 6 about here 
If the results found in the previous section are due to the true treatment moving the border and performing the same regressions as above should not display an effect of the fictitious treatment variable on social capital outcomes. Since no treatment took place in the regions that are placebo treated, they should not differ significantly in the outcome variables.

Table 7 about here

Results from this falsification test are shown in Table 7 . Columns (1) to (4) display the results from moving the border outwards, columns (5) to (7) respectively the results from a moving the border inwards. As it can be seen from columns (1), the one border movement suggests no statistically significant difference in the way people trust between placebo treated regions and controls. The coefficient is already small and increases further when state fixed effects are included in column (2). Controlling for other influences on the individual level only leads to a change in the sign of the treatment coefficient in column (3). Finally, including historical controls for initial shares of protestantism and urbanization rates do not change the result, as shown in column (4).

The finding of a non-significant treatment effect holds true for regressions of the treatment generated from moving the border inwards. While the coefficient of the fictitious treatment variable is now constantly negative, it is still insignificant, as shown in column (5). This is robust to including Federal States fixed effects in column (6), to control for further covariates in column (7) and for historical controls in column (8). This exercise allows to infer that only in the original border specification, using the correct border treatment, there exists a positive, significant and positive treatment effect for regions on the left of the border. Hence, the falsification tests and the original results suggest a peculiarity attributable to the Napoleonic influence.

\subsection{Comparing Pre-Treatment Characteristics}

While the border sample already cancels out much of pre-treatment heterogeneity, it is still possible that differences in initial regional characteristics drive my results. Ideally I would like to observe and compare regional pre-treatment levels of social capital. Since this is not possible given the lack of data, comparing pre-treatment characteristics that have been shown to be able to explain social capital levels in different contexts is the best feasible alternative. For this purpose I assembled data on several dimensions having been identified in the literature to matter for social capital levels and at the same time might give further insights about the reception of the Code Civil. For some variables this data is only available at 
the provincial level, and the limited number of observations make statistical tests inaccurate and to be interpreted carefully. Other variables are available on the city level such that common statistical mean comparison tests can be meaningfully interpreted. Table 8 reports the pre-treatment mean comparisons of those variables.

Table 8 about here

For the variables on the territory level and the complete sample shown in column (1) and (2), one can note that only for the number of years the French Army was present in a territory there exists a statistically significant difference. Treated regions were significantly longer occupied by the Napoleonic Army, which thus had more time to install the institutions properly. Second, treated regions are located closer to Paris, a characteristic important for whether a region was actually occupied or not. ${ }^{27}$ Third, the number of territories from which the regions were created is larger in the treated regions. Changing the institutions and going back to old institutions after the Napoleonic occupation was therefore much more costly in the light of the integration of those many small states. ${ }^{28}$ The comparison of the urbanization measures suggest that the treated regions were less urbanized before 1800. The literature on the determinants of social capital usually claims, that protestantism is favorable for social attitudes and cooperation (Alesina and La Ferrara, 2002; Tabellini, 2008). Thus, there exists a difference, while not significant, but unfavorable for social capital levels in the treated group. While I report the same comparisons for the regions of the border sample in column (3) and (4), the interpretation is not very meaningful given the tiny sample size.

Next, I investigate city level data taken from Jacob (2010) for a maximum of 364 cities located in the sample territories. Results are shown in the lower panel of Table 8 . The data contains information about whether the city was a free city, belonged to the Hanseatic Trade Cities, or was the seat of a bishop. I add a fourth variable identifying the existence of universities before 1800. In the spirit of Guiso, Sapienza, and Zingales (2008a) and Jacob (2010), past institutional characteristics associated with the free cities and the associated creation of norms of cooperation could have led to divergences in social capital levels before 1800 . However, neither the treated nor untreated group had on average significantly more free city states. As important as the free cities might have been the presence of the Hanseatic Cities, a corporation

\footnotetext{
${ }^{27}$ In contrast, one could reasonably assume, that, because of the closeness to France, people in the Western territory were much more in favor of the Revolutionary ideas when it break out in 1789, and thus much more involved in political activities, such as being member of Jacobin clubs. This was not the case. In the Rhineland for example, "there were hardly any local Jacobins or self-styled patriots sympathetic to the Revolution" (Doyle, 1990 p. 352) compared to other parts of Germany, and even if, these groups were small and consistent only of "scattered individual activists" (Sperber, 1992, p. 489).

${ }^{28}$ That a unified legal code made the integration of additionally gained territories easier was also emphasized by several scholars (see e.g. Becker, 1985, Arvind and Stirton, 2010).
} 
where cooperative cultural traits potentially have been fostered through its trade activities. Jacob (2010) for example finds that former Hanseatic cities show higher levels of social capital today. However, a the t-test indicates, significantly less of the cities in the treated regions were Hanseatic cities. A further city characteristic that is a positive correlate of social capital is the presence of a bishop. Again, I do not find any significant differences between treated and untreated cities. The same holds for the presence of early universities.

This simple exercise gives suggestive evidence that there was no clustering of important observable determinants of social capital in the treated regions. The most plausible explanations for the persistence of the Code Civil in some regions are thus the French occupation, as well as political factors, keeping in mind that the role of initial cultural differences cannot entirely be ruled out. ${ }^{29}$

\subsection{Alternative explanations}

I briefly discuss three alternative reforms Napoleon undertook that my treatment variable could capture, besides the effect of the Code Civil.

Education The educational reforms initiated by the French Emperor, particularly in the Rhineland, aimed at rearranging the school system to become free, equal and secular, introducing new school types, and teaching French as the territories' official language (Rowe, 2003, p. 120). This was the theory. In practice, however, the reform was a failure. Shortage of teacher and money led to the decay of the school system. ${ }^{30}$ With regard to higher education, the only academy created was the law school in Koblenz (Rowe, 2003, p. 137). When Prussia took over the territory of the Rhine, it pushed back the leftovers of the French rule, adapted the school system to the Prussian, and opened universities as in Bonn to educate new bureaucrats for the Empire (Rowe, 2003, p. 134).

Administration Another Napoleonic reform consisted in the introduction of the civil administration and its centralization. The new Prussian rulers, however, reformed the local and provincial government immediately after the takeover of the Rhineland in April 1815. While the very local administration

\footnotetext{
${ }^{29}$ Arvind and Stirton (2010) research the question, what makes a region keep the Code Civil after the Napoleonic invasion. They find that there is no single factor explaining the reception of the legal Code. Rather a set of factors was responsible, including amongst others direct French control, and the number of territories the region gained in 1815. Direct French control is surely an important factor, as well as the number of years the Code Civil was in in force before 1815. Those aspects made it more costly to abandon the Code Civil afterwards.

${ }^{30}$ In the Rhineland three forth of the population could not read and write in 1814 and regular schooling was an exception (Schmenk, 2008, p. 232)
} 
system was continued, i.e. on the level of the mayoralty, superior administration levels were adapted to the Prussian one, which itself had introduced a civil administration under its reformer Stein in the meantime (Rowe, 2003).

Political Rights Changes in the elite structure might have led to a new balance of power and an increase in citizens' political rights. As the Rhineland was given to Prussia, its citizens ended up having the same political rights as other Prussians. While the Prussian King promised to introduce a constitution and to introduce a supra-regional parliament in 1815 , he did not keep it. The lack of political rights is consistent with recent data collected. ${ }^{31}$

These examples suggest that only the Code Civil endured the immediate period of French occupation and could therefore impact beliefs in the long-run. Furthermore, the results of the both the complete and border sample hold true even within Prussia, that is holding those variables constant

\section{Trade Employment and Social Capital in 19Th CEnTURy}

\section{PRUSSIA}

The results from the previous estimations have shown that regions that applied the Napoleonic institutions throughout the 19th century have higher levels of trust, more than 200 years after its installment. However, 200 years is an enormous time span, and other shocks happening had the potential to destroy or to generate social capital. The following section thus has two aims: It first aims at giving support for the proposed channel going through economic cooperation, and second to show immediate spillover effects on cooperation outside the work environment. It will do so by looking at employment in trade, manufacturing and craft, as well as at 19th century associational participation within a sample of Prussian counties.

I will begin by investigating a possible link between the Napoleonic institutions and employment in trade, manufacturing and craft in 19th century Prussia. It is reasonable to expect the Code Civil to having had a positive influence on commercial activities. Already Adam (Smith, 1776, p. 862) stressed the importance of institutions for "[c]ommerce and manufactures [to] flourish", Milgrom, North, and

\footnotetext{
${ }^{31}$ Tabellini $(2010)$ measured the constraints of the executive on the regional level in 1800 and 1850 on scale from 1 (no constraints) to 7 (democracy) and reports for both dates a value of 1 for the Rhineland and 2 for Baden. This is very much in line with the quality of other German regions at that time, ranging from a minimum of 1 to a sample maximum of 3 (Bavaria) and and an overall maximum of 4 (Bremen, Hamburg).
} 
Weingast (1990) emphasized the role of the medieval merchant courts for the evolution of interpersonal exchange, De Long and Shleifer (1993) those of constraints on the executive for city growth and more recently Cantoni and Yuchtman (2012) show that legal training in Universities and subsequent evolution of legal institutions was causing greater market activity in medieval Germany. Closest to this paper is of course Acemoglu et al. (2011), who established a relation between the Napoleonic institutions and urbanization rates. I use the share of people working in trade related jobs, such as goods or money trader, as a proxy for trade in mid-19th century Prussia. Trade, however, only measures the last step of the production chain and therefore underestimates economic cooperation. To capture broader effects on economic interaction, I include additionally employment in factories and craft. Trade, manufacturing and craft professions naturally require not only a high degree of cooperation and trust, but they also profit the most from a third party enforcement institutions.

As work-related cooperation increases, cooperation outside the workplace should be affected, too. Outside-workplace cooperation basically includes all cooperative actions outside professional activities that do not have the aim of an (immediate) economic payoff. This includes the participation in associations, or other forms of voluntary or political engagements characterizing an active civil society. ${ }^{32}$ Three main forms of associations existed in 19th century Prussia. Those were the singer clubs, the gymnasts, and the shooters (often jointly referred to as the "cloverleaf") (Klenke, 1998, p. 20). Those clubs were engaged in all kinds of community life, especially important for organizing big folk festivals (Klenke, 1998, p. 20). The markmen's festival (Schützenfest), organized by the shooters were attracting sometimes hundreds of people. Data is available for two of the three kinds of associations, used as a proxy for social capital in the 19th century. In particular, I look at the number of gymnast clubs in a crosssection of Prussian counties. Gymnast clubs have another interesting feature I will make use of. Besides being a sports association in which people where doing gymnastic exercises, they were also providing a public good, as volunteer gymnast fire departments (Turnfeuerwehren) were created out of them. As such they are the predecessors of contemporaneous volunteer fire departments. Since gymnasts were in good shape, they were best suited to do the demanding job of a firemen at that time, which required to run the hand-operated fire-engine and climbing into houses. Thus, many gymnast clubs created fire departments where members worked voluntarily as firemen. The second data set being used is listing the foundation of shooting associations from 1700 to 1900 for each county in the two Prussian provinces Rhineland and Westphalia. I will analyze the development of shooting associations in the neighboring

\footnotetext{
${ }^{32}$ Associational membership has been used in several contributions to proxy for contemporaneous and historical levels of social capital. The idea that social capital can be measured by the degree of associational activity goes back to Putnam (1994)).
} 
regions Rhineland, which kept the Code Civil, and Westphalia, which did not. One would expect a positive association between the Napoleonic institutions on the number of associations created.

\subsection{Historical Data}

The detailed historical data sources and the variables constructed out of them are listed in the following.

Trade Occupation, Income, Religion, Education, Population in 19th century Prussia The first set of data covers employment shares and controls to be used on the county level in 19th century Prussia. Starting in 1816, the Royal Prussian Statistical Office collected throughout the 19th century data on population, education, religious denomination, occupation, and tax income. Several different waves of the Prussian Statistics are used and combined. For measuring the development of the trade sector in 19th century, I use the data on occupation gathered in 1849. The data lists the number of people working in trade related jobs, such as wholesaler, mercer, spice-trader, or broker, and other occupations, such as civil servants or servants "for the convenience of the lordship". My measure of trade occupations, Trade, divides the total number of people working in trade related jobs by the county's population. I also use the per capita share of individuals employed in factories, except mills, in 1849 as a measure of industrialization, following Becker, Hornung, and Woessmann (2011b). I label this variable Factory. Furthermore, the variable Craft gives per capita share of employment in craft, and encompasses jobs as baker, tailor or music instrument maker. $\mathrm{TrFaCr}$ combines the previous three variables. Counterfactuals, on which no effects are expected, are the number of people working as civil servants as a share of the population, and the number of male servants per capita. Several controls taken from the 1864 dataset are included, such as the share of Protestant and Jewish population, the share of females, the number of elementary schools per capita. Following Becker and Woessmann (2009), the counties' income tax per capita in 1878 will proxy for per capita economic prosperity. The source of the data is Becker et al. (2012), who compiled the data from the original Prussian statistics. Furthermore, I assign to every county its geographic location, that is a measure for longitude and latitude. ${ }^{33}$

Gymnasts and Volunteer Fire Departments The source for the gymnasts clubs and the fire departments is the Second Statistical Yearbook of German Gymnast Clubs (Zweites statistisches Jahrbuch Deutscher Turnvereine) from 1865 (Hirth, 1865). ${ }^{34}$ It lists all German gymnast clubs existing at that time and

\footnotetext{
${ }^{33}$ Table B.2 in the Appendix lists the territories included in the sample and the treatment.

${ }^{34}$ See Data Appendix for further information.
} 
furthermore provides information on whether the club had a fire department, and if yes, the number of firemen. From this data, I construct the per capita amount of firemen per county, Firemen p.c., as a first measure of social capital, and second the total number of clubs per county, labeled No of Clubs.

Shooting Associations As a last measure of social capital for 19th century Germany, I use a dataset for the two Prussian provinces Rhineland and Westphalia that contains the number of German shooting associations (Schützenvereine) founded per county from the Middle Ages to 1939 at a yearly level. ${ }^{35}$ I use the years from 1700 to 1900 . The source is Plett (1991), who gathered this data by directly by surveying current day shooting clubs about their year of foundation. In the data, a club is reported to exist in year $\mathrm{t}$, if its date of foundation falls in this year.

Summary Statistics for the variables generated out of the historical data sources are displayed in Table 9

Table 9 about here

\subsection{The Impact on Trade, Factory and Craft Employment}

Table 10 displays the regression results of estimating the following model:

$$
Y_{c, p}=\alpha+\delta * \operatorname{code}_{c}+X_{c, p}^{\prime} * \beta+u_{c, p}
$$

where $Y_{c, p}$ gives the relative occupational share in county c located in Prussian province $\mathrm{p}$. The variable $\operatorname{code}_{c}$ is a dummy indicating whether county $\mathrm{c}$ used the code civil or not. $X_{c, p}^{\prime}$ includes the controls listed above.

\section{Table 10 about here}

Counties applying the Code Civil are associated with a significantly higher occupational share in trade, see column (1). Conditionally on other controls, adopting the Code Civil goes along with an increase in the trade share by 0.004 in absolute values (column (2)), or about 0.66 of a standard deviation in trade. Treated regions also have higher levels of industrialization, as measured by the per capita share of employment in factories (column (3)) and a higher share craftsmen (column (4)). The effects are equally large, as adopting the Code Civil increases factory and craft employment by about 50 percent of the relevant standard deviation. They are furthermore comparable both in magnitude and significance

\footnotetext{
${ }^{35}$ See Data Appendix for further information.
} 
to those using the composition of trade, factor employment and craft as dependent variable in columns (5) and (6). Making use of the counterfactuals, I run the regression with the share of civil servants and servants as dependent variables. The regressions, see columns (7) and (8), report non-significant, negative associations between the Code Civil and the employment share in the civil sector, as well as the per capita share of servants.

\subsection{The Impact on Gymnast Clubs and Volunteer Fire Departments}

To assess the impact on the number of gymnast clubs and firemen, the following model is regressed:

$$
G_{c, p}=\alpha+\delta * \operatorname{cod} e_{c}+X_{c, p}^{\prime} * \beta+u_{c, p}
$$

where $G_{c, r, p}$ is one of the following dependent variables measured in county c in province p: Member p.c. gives the per capita share of members in gymnast clubs. Firemen p.c. gives the per capita share of voluntary firemen per county. Member gives the total number members in gymnast clubs. Firemen gives the total number volunteer firemen per county. The variable code $e_{c}$ is a dummy indicating whether county $\mathrm{c}$ used the code civil or not. $X_{c, p}^{\prime}$ includes the controls listed above.

\section{Table 11 about here}

As Table 11 shows, there exists a positive correlation between the Code Civil and gymnast club membership, as well as volunteer firemen departments. Columns (1) and (2) indicate that in counties applying the Napoleonic legal code, the per capita share of club members and firemen is higher. Switching from 0 (no Code) to 1 (adopting the Code) increases the participation in gymnast clubs per capita by on average about 35 percent of its sample mean. The number of volunteer firemen per capita increases by a magnitude of on average 20 percent of the sample mean for regions that adopted the Code Civil. This finding is robust to using total numbers of members and firemen, as columns (3) and (4) show, and population is controlled for. When education and the share of females are included in the regression, the coefficients of interest stay significant on the 10 percent significance level in column (5), as well as in column (6).

Finally, regressions of the social capital measures on economic cooperation display a strong positive correlation of membership in gymnast clubs, as well as voluntary participation as firemen, with trade and factory employment. Table 12 shows this correlation in columns (1) to (6), which is robust to including potential covariates in columns (7) to (12). 
Table 12 about here

\subsection{The Impact on Shooting Associations}

To test empirically if the Napoleonic treatment in the Rhineland resulted in a higher number of shooting clubs founded per year compared to Westphalia, I use the foundation dates of shooting clubs available in a panel of 128 districts and an annual time period from 1700 to 1900 . I aggregate the data on the district level into four different periods composed of 50 years, i.e. $1700-1750,1750-1800,1800-$ 1850 and $1850-1900 .^{36}$ I run a set of binary regressions - equivalent to simple t-tests - comparing the mean number of clubs founded per province per period. Results are shown in Table 13 .

\section{Table 13 about here}

The results indicate that both provinces did not differ significantly in the average number of clubs founded during the period from 1700 to 1750 . However, starting from the second period I find a significant differences between the two provinces. From 1750 to 1800 on average an addition of 0.3 shooting clubs per district were founded in Westphalia. The negative difference aggravates in the period between 1800 and 1850. Only from 1850 onwards, a the sign of the mean difference changes and gets positive. From 1850, more clubs were founded in the Rhineland using the Code Civil then in the neighboring province of Westphalia. ${ }^{37}$ The same pattern shows up when the lagged cumulative number of clubs per district is controlled for in Panel B. On the one hand should be cautious generalizing those results, as the type of association is particular. An explanation for the spike in the number of clubs founded in Westphalia in the years from 1800 to 1850 could, for example, be the high number of veterans returning from the Napoleonic wars. On the other hand, the evidence shows roughly the expected pattern. While before 1800 there was no or even a negative different in associations in the Rhineland vs Westphalia, this trend turns during the 19th century.

\subsection{Summary: Trade and Associations in 19th century Prussia}

This section using historical social capital supports the findings described in section 3. Although each regression by itself might have drawbacks, as they do not account for unobserved heterogeneity on the

\footnotetext{
${ }^{36}$ The reason for aggregating the data rather than running a panel regression comes from the concern that in a panel regression, serial and spatial correlation potentially bias the estimation results. With only two cross-sectional units for which the treatment varies, and thus only two potentially cluster, clustering is in this case not a feasible option to account for this. See also Bertrand, Duflo, and Mullainathan (2003).

${ }^{37}$ Running regressions with panel data produces the same results.
} 
county (or province) level by applying county level (or provincial level) fixed effects as two of the regressions use cross-sectional data, the overall picture points in one direction: Those Prussian counties that belonged to the province of Rhineland and that kept the Code Civil, have had both a higher share of people engaging in impersonal trade, factory work and craft, and at the same time more engagement in civic associations. Assuming that all counties started out with comparable characteristics before Napoleon imposed the Code Civil to those regions, the increase in institutional quality causally impacted trade and associational participation. Those effects give a rational for the observed differences in contemporaneous differences in trust.

Lastly, one could ask if there is evidence that cooperation persisted. Putnam (1994) for example shows remarkable persistence of associational participation in Italy between 1900 and 1970 by using comparable measures of club membership. To elicit persistence of cooperation, I therefore regress individual responses for Trust on the employment shares, as well as per capita firemen and gymnast membership in 19th century Prussia.

\section{Table 14 about here}

Table 14 displays that only the employment shares can explain current trust significantly (see columns (1) -(6)). Both, firemen and membership do not show any significant association. One explanation for the latter might be that the share of people that were actually engaged in historical associations are relatively low and that historical and current indicators of social capital used are quite different. The positive association between current trust and past employment holds even when the entire set of individual controls is included in the regressions (see columns (7) - (12)). It seems that, consistent with my initial hypothesis, economic exchange played an important role for generating trust.

\section{CONCLUSION}

This paper provides evidence that impartial legal enforcement institutions can increase norms of trust and cooperation on the very local level. I explored variation in the quality of legal institutions generated by the historical experiment of the introduction of the Code Civil in 19th century Germany. Results obtained from the empirical analysis documented a strong complementarity between having applied the Code Civil and contemporaneous norms of cooperation in the German SOEP dataset. Identification from individuals living in closely located border regions, a falsification test consisting in moving the border, the 
comparison of pre-treatment characteristics, and the discussion of alternative possible influences point towards a causal interpretation of these findings. In addition, the same positive relationship is obtained from an additional source of evidence drawn from trade and social capital measures in 19th century Prussia. The findings suggest persistence of values even within a contemporaneous country's unified legal framework and relates to the striking persistent effects of institutions described in the literature. As beliefs generated by a strong law persist in this example, persistence of norms should be exacerbated in societies where formal institutions persisted to be weak. Consequently, mistrust generated in the past by a lax rule of law is one likely channel explaining current institutional failure characterizing many less developed countries.

A remark on the interaction between institutions, social capital and growth concludes the paper. The Napoleonic institutions did not only affect the social structure of the affected societies, those regions also experienced higher economic growth than their untreated counterparts, as Acemoglu et al. (2011) have shown. A joint feature of most contributions researching the effect of institutions on economic outcomes is, however, that the question how better institutional environments transform into faster economic growth remains unanswered. While the impact of institutions on aggregated economic outcomes is convincingly established, whether institutions affect individual behavior of cooperation necessary for economic transactions is unclear. Linking my results to this paper, an appealing conclusion would be to emphasize the effects of institutions on individual cooperative behavior and the creation of norms of cooperation and trust as a rational for this relationship, i.e. this "missing channel". The "environment conducive to innovation and entrepreneurial activity" the Code Civil created according to Acemoglu et al. (2011), does then, besides the institutional framework, include norms and values favorable to economic growth generated by those institutions. Thus, the Napoleonic institutions might have kicked off a feedback loop between norms of trust and economic payoffs, reinforcing each other mutually. To a certain extent this remains speculation, as the question whether institutions are linked to economic outcomes through the formation of social capital has not be answered quantitatively in this paper. Certainly, this is an interesting avenue for further research.

Taken together, the results indicate that increasing the quality of legal institutions and allowing people to interact economically has beneficial effects for interpersonal trust. This can amplify the positive effect institutions have for economic development. 


\section{REFERENCES}

Acemoglu, D., S. Johnson, and J. Robinson (2001). "The Colonial Origins of Comparative Development: An Empirical Investigation”. The American Economic Review 91.5, pp. 1369-1401.

Acemoglu, D., D. Cantoni, S. Johnson, and J. Robinson (2011). "The Consequences of Radical Reform: The French Revolution". The American Economic Review 101.7, pp. 3286-3307.

Aghion, P., Y. Algan, P. Cahuc, and A. Shleifer (2010). "Regulation and Distrust". The Quarterly Journal of Economics 125.3, pp. 1015-1049.

Alesina, A. and E. La Ferrara (2002). "Who Trusts Others?” Journal of Public Economics 85.2, pp. 207234.

Algan, Y. and P. Cahuc (2010). "Inherited Trust and Growth". The American Economic Review 100.5, pp. 2060-2092.

— (2013). "Trust and Human Development: Overview and Policy Implications". In: Handbook of Economic Growth. Vol. 1A-2013. Aghion, P. and Durlauf, S.

Arvind, T. and L. Stirton (2010). "Explaining the Reception of the Code Napoleon in Germany: A FuzzySet Qualitative Comparative Analysis”. Legal Studies 30.1, pp. 1-29.

Becker, H. (1985). "Das Rheinische Recht und seine Bedeutung für die Rechtsentwicklung in Deutschland im 19. Jahrhundert". Juristische Schulung 25, pp. 338-345.

Becker, S. O., E. Hornung, and L. Woessmann (2011b). "Education and Catch-Up in the Industrial Revolution”. American Economic Journal: Macroeconomics 3.3, pp. 92-126.

Becker, S. and L. Woessmann (2009). "Was Weber Wrong? A Human Capital Theory of Protestant Economic History". The Quarterly Journal of Economics 124.2, pp. 531-596.

Becker, S., K. Boeckh, C. Hainz, and L. Woessmann (2011a). “The Empire Is Dead, Long Live the Empire! Long-Run Persistence of Trust and Corruption in the Bureaucracy”. CEPR Discussion Paper 8288.

Becker, S., F. Cinnirella, E. Hornung, and L. Woessmann (2012). "iPEHD-The ifo Prussian Economic History Database”. CESifo Working Paper No. 3904.

Bertrand, M., E. Duflo, and S. Mullainathan (2003). "How Much Should We Trust Differences-inDifferences Estimates?" mimeo.

Bisin, A. and T. Verdier (2001). "The Economics of Cultural Transmission and the Dynamics of Preferences". Journal of Economic Theory 97.2, pp. 298-319. 
Cantoni, D. and N. Yuchtman (2012). "Medieval Universities, Legal Institutions, and the Commercial Revolution".

Cassar, A., G. d'Adda, and P. Grosjean (2012). "Institutional Quality, Culture, and Norms of Cooperation: Experimental Evidence from Italy and Kosovo". mimeo.

De Long, J. B. and A. Shleifer (1993). "Princes and Merchants: European City Growth before the Industrial Revolution". Journal of Law and Economics 36.2, pp. 671-702.

Dohmen, T., A. Falk, D. Huffman, and U. Sunde (2012). "The Intergenerational Transmission of Risk and Trust Attitudes". The Review of Economic Studies 79.2, pp. 645-677.

Doyle, W. (1990). The Oxford History of the French Revolution. Oxford University Press (Oxford and New York).

Fehr, E. and S. Gächter (2000). "Cooperation and Punishment in Public Goods Experiments”. The American Economic Review 90.4, pp. 980-994.

Fisman, R. and E. Miguel (2007). "Corruption, Norms, and Legal Enforcement: Evidence from Diplomatic Parking Tickets". Journal of Political Economy 115.6, pp. 1020-1048.

Glaeser, E. L., R. La Porta, F. Lopez-de Silanes, and A. Shleifer (2004). “Do Institutions Cause Growth?” Journal of economic Growth 9.3, pp. 271-303.

Grab, A. (2003). Napoleon and the Transformation of Europe. Palgrave Macmillan.

Guiso, L., P. Sapienza, and L. Zingales (2008a). “Long Term Persistence”. NBER Working Paper 14278.

- (2008b). "Social Capital as Good Culture". Journal of the European Economic Association 6.2-3, pp. 295-320.

— (2010). "Civic Capital as the Missing Link". NBER Working Paper 15845.

Hirth, G. (1865). Zweites Statistisches Jahrbuch der Turnvereine Deutschlands. Leipzig.

Jacob, M. (2010). “Long-Term Persistence: The Free and Imperial City Experience in Germany”. mimeo.

Jacob, M. and M. Tyrell (2010). “The Legacy of Surveillance: An Explanation for Social Capital Erosion and the Persistent Economic Disparity between East and West Germany". mimeo.

Klenke, D. (1998). Der singende deutsche Mann: Gesangsvereine und deutsches Nationalbewusstsein von Napoleon bis Hitler. Muenster: Waxmann Verlag.

La Porta, R., F. López-de-Silanes, and A. Shleifer (2008). “The Economic Consequences of Legal Origins". Journal of Economic Literature 46.2, pp. 285-332.

López-de-Silanes, F., R. La Porta, A. Shleifer, and R. Vishny (1998). "Law and Finance”. Journal of Political Economy 106, pp. 1113-1155. 
Lyons, M. (1994). Napoleon Bonaparte and the Legacy of the French Revolution. Vol. 1. Palgrave Macmillan.

Milgrom, P., D. North, and B. Weingast (1990). "The Role of Institutions in the Revival of Trade: the Law Merchant, Private Judges, and the Champagne Fairs". Economics and Politics, pp. 1-23.

Nipperdey, D. (1983). Deutsche: Geschichte 1800-1866: Bürgerwelt und starker Staat, Munich. Munich: C.H. Beck.

Nunn, N. (2012). "Culture and the Historical Process". Economic History of Developing Regions 27, pp. 108-126.

Nunn, N. and L. Wantchekon (2011). "The Slave Trade and the Origins of Mistrust in Africa". The American Economic Review 101.7, pp. 3221-3252.

Plett, W. (1991). The Rifle Clubs in the Rhineland and in Westphalia 1789-1939. Vol. ZA8112 Data file Version 1.0.0. GESIS Data Archive, Cologne.

Putnam, R. (1994). Making Democracy Work: Civic Traditions in Modern Italy. Princeton university press.

Rowe, M. (2003). From Reich to State: the Rhineland in the Revolutionary Age, 1780-1830. Cambridge University Press.

Schmenk, H. (2008). Xanten im 19. Jahrhundert. Böhlau Verlag Köln.

Smith, A. (1776). “The Wealth of Nations (1937)”. New York: Modern Library 11937.

Sperber, J. (1992). Rhineland Radicals: The Democratic Movement and the Revolution of 1848-1849. Princeton University Press.

Stein, W. H. (2004). Die Bedeutung des Code Civil für Deutschland - Revolutionäres Recht - Imperiales Recht - Liberales Recht. Speech Manuscript.

Tabellini, G. (2008). "The Scope of Cooperation: Values and Incentives". The Quarterly Journal of Economics 123.3 , pp. 905-950.

- (2010). "Culture and Institutions: Economic Development in the Regions of Europe". Journal of the European Economic Association 8.4, pp. 677-716.

Voigtländer, N. and H. Voth (2012). "Persecution Perpetuated: The Medieval Origins of Anti-Semitic Violence in Nazi Germany”. The Quarterly Journal of Economics 127.3, pp. 1339-1392.

Wagner, G., J. Frick, and J. Schupp (2007). “The German Socioeconomic Panel Study (SOEP): Scope, Evolution and Enhancements". Schmollers Jahrbuch 127, pp. 139-169. 


\section{A TABles}

Table 1: Summary Statistics: Individual Data

\begin{tabular}{|c|c|c|c|c|c|c|c|c|c|c|c|}
\hline \multirow[b]{3}{*}{ Treatment } & \multicolumn{5}{|c|}{ Full Sample } & \multicolumn{3}{|c|}{ Border $=0$} & \multicolumn{3}{|c|}{ Border $=1$} \\
\hline & $N$ & Mean & StDev & $\operatorname{Min}$ & $\operatorname{Max}$ & $N$ & Mean & StDev & $N$ & Mean & StDev \\
\hline & & & & & & & & & & & \\
\hline Code Civil & 15096 & 24.306 & 37.246 & 0 & 98 & 2644 & 3.394 & 4.434 & 2334 & 95.820 & 3.563 \\
\hline Border & & & & & & 2644 & 0 & 0 & 2334 & 1 & 0 \\
\hline \multicolumn{12}{|l|}{ Dependent variables } \\
\hline Trust & 15096 & 2.318 & 0.535 & 1 & 4 & 2644 & 2.333 & 0.543 & 2334 & 2.376 & 0.553 \\
\hline Fair & 15096 & 0.536 & 0.499 & 0 & 1 & 2644 & 0.559 & 0.497 & 2334 & 0.585 & 0.493 \\
\hline Help & 15096 & 0.362 & 0.481 & 0 & 1 & 2644 & 0.356 & 0.479 & 2334 & 0.435 & 0.496 \\
\hline Family & 15039 & 2.725 & 0.932 & 1 & 5 & 2630 & 2.722 & 0.912 & 2326 & 2.709 & 0.970 \\
\hline \multicolumn{12}{|l|}{ Control variables } \\
\hline \multicolumn{12}{|l|}{ Personal Characteristics } \\
\hline Age & 15096 & 47.648 & 17.206 & 17 & 100 & 2644 & 47.402 & 16.937 & 2334 & 47.758 & 17.235 \\
\hline Age sq. & 15096 & 2566.324 & 1717.515 & 289 & 10000 & 2644 & 2533.705 & 1682.267 & 2334 & 2577.733 & 1752.774 \\
\hline Male & 15096 & 0.486 & 0.5 & 0 & 1 & 2644 & 0.486 & 0.5 & 2334 & 0.484 & 0.5 \\
\hline GDR before 1990 & 15096 & 0.288 & 0.453 & 0 & 1 & 2644 & 0.042 & 0.201 & 2334 & 0.036 & 0.186 \\
\hline \multicolumn{12}{|l|}{ Economic Controls } \\
\hline $\mathrm{HH}$ income & 15096 & 2864.587 & 2081.275 & 0 & 85000 & 2644 & 3155.902 & 2042.265 & 2334 & 3147.819 & 1931.394 \\
\hline Unemployment & 15096 & 0.065 & 0.247 & 0 & 1 & 2644 & 0.039 & 0.194 & 2334 & 0.042 & 0.201 \\
\hline \multicolumn{12}{|l|}{ Education } \\
\hline Secondary School (13 years) & 15096 & 0.212 & 0.409 & 0 & 1 & 2644 & 0.213 & 0.410 & 2334 & 0.243 & 0.429 \\
\hline Secondary School (12 years) & 15096 & 0.052 & 0.222 & 0 & 1 & 2644 & 0.061 & 0.238 & 2334 & 0.067 & 0.250 \\
\hline Middle School (10 years) & 15096 & 0.313 & 0.464 & 0 & 1 & 2644 & 0.266 & 0.442 & 2334 & 0.241 & 0.428 \\
\hline Middle School (9 years) & 15096 & 0.373 & 0.484 & 0 & 1 & 2644 & 0.404 & 0.491 & 2334 & 0.404 & 0.491 \\
\hline Other degree & 15096 & 0.011 & 0.105 & 0 & 1 & 2644 & 0.009 & 0.093 & 2334 & 0.009 & 0.097 \\
\hline No degree & 15096 & 0.038 & 0.192 & 0 & 1 & 2644 & 0.046 & 0.209 & 2334 & 0.036 & 0.187 \\
\hline \multicolumn{12}{|l|}{ Religion } \\
\hline Protestant & 15096 & 0.358 & 0.479 & 0 & 1 & 2644 & 0.424 & 0.494 & 2334 & 0.370 & 0.483 \\
\hline Catholic & 15096 & 0.306 & 0.461 & 0 & 1 & 2644 & 0.359 & 0.480 & 2334 & 0.452 & 0.498 \\
\hline Other Christian & 15096 & 0.009 & 0.092 & 0 & 1 & 2644 & 0.019 & 0.135 & 2334 & 0.005 & 0.069 \\
\hline Other Non-Christian & 15096 & 0.005 & 0.069 & 0 & 1 & 2644 & 0.009 & 0.093 & 2334 & 0.005 & 0.072 \\
\hline None & 15096 & 0.323 & 0.467 & 0 & 1 & 2644 & 0.189 & 0.392 & 2334 & 0.169 & 0.375 \\
\hline \multicolumn{12}{|l|}{ Historical Controls } \\
\hline Urbrate 1800 & 15096 & 11.238 & 5.321 & 3.336 & 22.500 & 2644 & 6.426 & 1.477 & 2334 & 11.506 & 4.071 \\
\hline Protestant 1800 & 15096 & 0.591 & 0.365 & 0.050 & 1 & 2644 & 0.554 & 0.203 & 2334 & 0.298 & 0.093 \\
\hline Urbrate 1850 & 15096 & 15.700 & 7.973 & 5.442 & 33.291 & 2644 & 8.212 & 2.821 & 2334 & 16.190 & 4.926 \\
\hline Latitude & 15096 & 50.743 & 1.733 & 48.133 & 54.517 & & & & & & \\
\hline Longitude & 15096 & 10.195 & 2.131 & 7.600 & 13.733 & & & & & & \\
\hline Dist. Paris & 15096 & 626.422 & 162.176 & 403.661 & 851.013 & & & & & & \\
\hline
\end{tabular}


Table 2: Complete Sample

\begin{tabular}{|c|c|c|c|c|c|c|c|c|c|c|}
\hline & $\begin{array}{c}\text { (1) } \\
\text { Trust }\end{array}$ & $\begin{array}{c}(2) \\
\text { Help }\end{array}$ & $\begin{array}{l}\text { (3) } \\
\text { Fair }\end{array}$ & $\begin{array}{c}\text { (4) } \\
\text { Trust }\end{array}$ & $\begin{array}{c}(5) \\
\text { Help }\end{array}$ & $\begin{array}{l}\text { (6) } \\
\text { Fair }\end{array}$ & $\begin{array}{c}(7) \\
\text { Family }\end{array}$ & $\begin{array}{c}(8) \\
\text { Trust }\end{array}$ & $\begin{array}{c}(9) \\
\text { Help }\end{array}$ & $\begin{array}{l}(10) \\
\text { Fair }\end{array}$ \\
\hline Code Civil (x100) & $\begin{array}{c}0.0465 * * * \\
(0.0150)\end{array}$ & $\begin{array}{c}0.0852 * * * \\
(0.0232)\end{array}$ & $\begin{array}{c}0.0338 * * \\
(0.0133)\end{array}$ & $\begin{array}{l}0.0420 * \\
(0.0208)\end{array}$ & $\begin{array}{c}0.0821 * * * \\
(0.0244)\end{array}$ & $\begin{array}{c}0.0307 * \\
(0.0157)\end{array}$ & $\begin{array}{l}0.00293 \\
(0.0319)\end{array}$ & $\begin{array}{c}0.0887 * * * \\
(0.0271)\end{array}$ & $\begin{array}{c}0.149 * * * \\
(0.0389)\end{array}$ & $\begin{array}{c}0.0476 * * * \\
(0.0142)\end{array}$ \\
\hline Individual Controls & No & No & No & Yes & Yes & Yes & Yes & Yes & Yes & Yes \\
\hline Religion (4 categories) & No & No & No & Yes & Yes & Yes & Yes & Yes & Yes & Yes \\
\hline Education ( 5 categories) & No & No & No & Yes & Yes & Yes & Yes & Yes & Yes & Yes \\
\hline Economic controls & No & No & No & Yes & Yes & Yes & Yes & Yes & Yes & Yes \\
\hline Historical Controls & No & No & No & No & No & No & No & Yes & Yes & Yes \\
\hline Macroregion FE & Yes & Yes & Yes & Yes & Yes & Yes & Yes & Yes & Yes & Yes \\
\hline Observations & 15096 & 15096 & 15096 & 15096 & 15096 & 15096 & 15039 & 15096 & 15096 & 15096 \\
\hline R-Squared & 0.013 & 0.008 & 0.009 & 0.075 & 0.045 & 0.042 & 0.024 & 0.077 & 0.048 & 0.043 \\
\hline
\end{tabular}

Notes: OLS regressions. Dependent variables: Trust is the average of answers given to the following questions: "On the whole one cannot trust people", "Nowadays one can't rely on anyone" "If one is dealing with strangers, it is better to be careful before one can trust them". Help: The question asks "Would you say that for most of the time, people..." and the variable takes on the value 1 for a the response "attempt to be helpful" and 0 for the response "or only act in their own interests". Fair: The question asks "Do you believe that most people..." and the variable takes on the value 0 for a the response "would exploit you if they had the opportunity" and 1 for the response "or would attempt to be fair towards you". Family: The question asks "Please indicate how often you take part in each activity: Visits to and from family members and relatives". The variable is measured of a 5 point scale, where 1 indicates "daily", 2 "at least once a week", 3 "at least once a month", 4 "seldom", 5 "never". Source: German Socio-Economic Panel, wave 2003.

Historical controls include the longitude and latitude of the historical territory, the share of protestants in 1800 , the urbanization rates in 1800 and 1850 , as well as the territory's distance to Paris.

Heteroscedastic-robust standard errors in parentheses, clustered at the historical territory. ${ }^{*} p<0.10,{ }^{* *} p<0.05,{ }^{* * *} p<0.01$ 


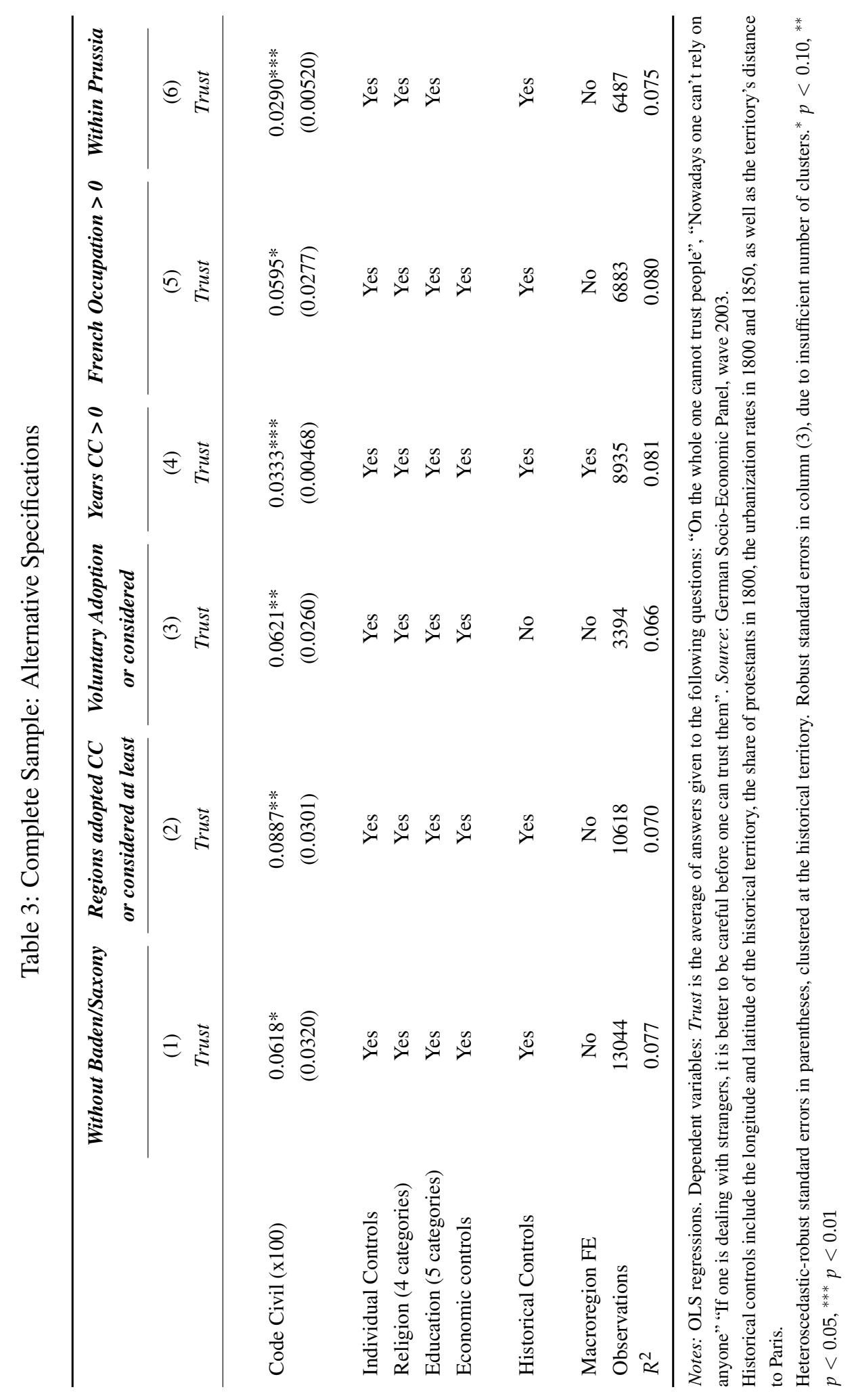




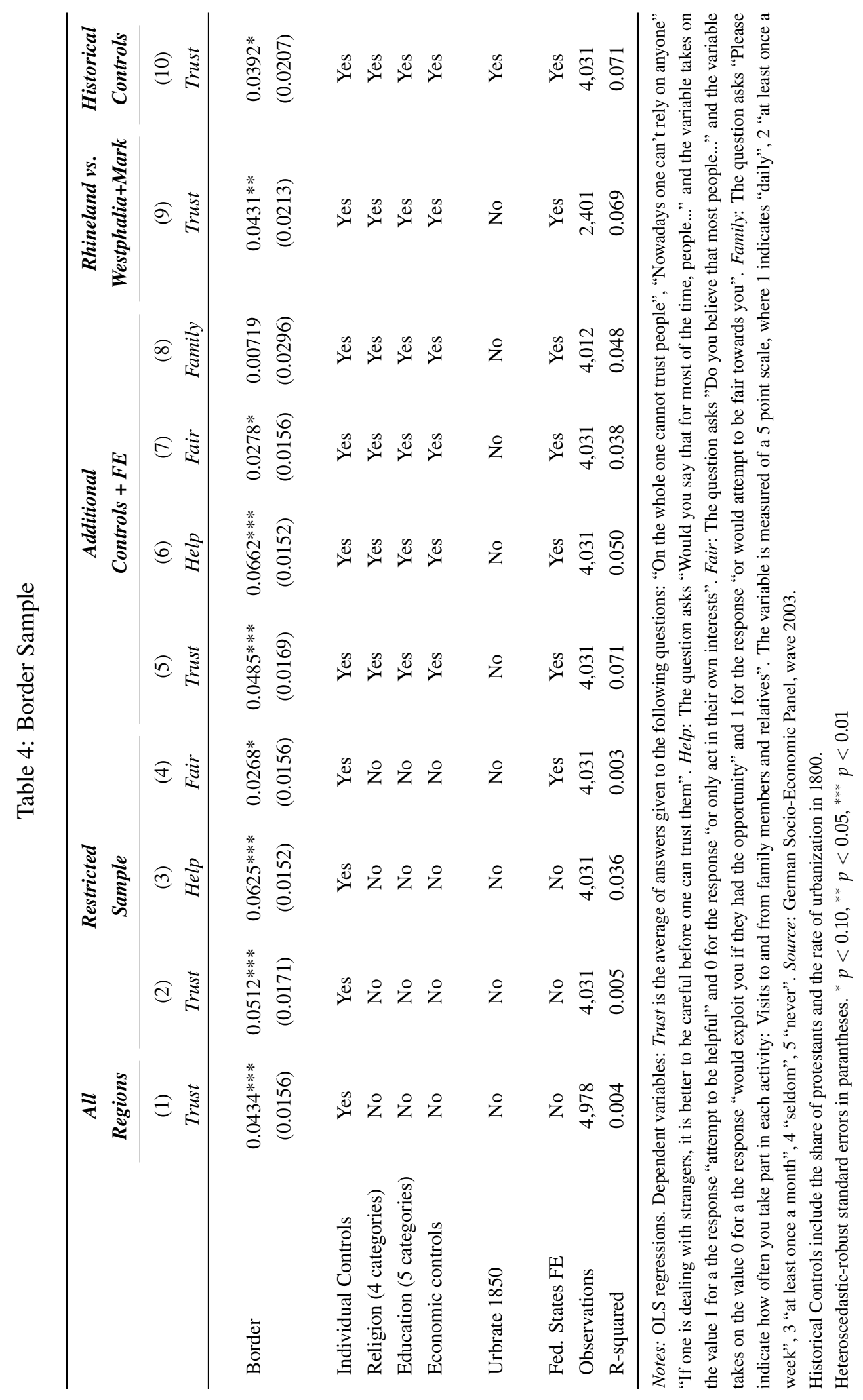


Table 5: Border Sample: Robustness to Alternative Historical Controls

\begin{tabular}{|c|c|c|c|c|}
\hline & $\begin{array}{l}\text { (1) } \\
\text { Trust }\end{array}$ & $\begin{array}{l}\text { (2) } \\
\text { Trust }\end{array}$ & $\begin{array}{l}\text { (3) } \\
\text { Trust }\end{array}$ & $\begin{array}{l}\text { (4) } \\
\text { Trust }\end{array}$ \\
\hline \multirow[t]{2}{*}{ Border } & $0.0392 *$ & $0.0407 * *$ & $0.0478 * *$ & $0.0502 *$ \\
\hline & $(0.0207)$ & $(0.0199)$ & $(0.0200)$ & $(0.0281)$ \\
\hline \multirow[t]{2}{*}{ Urbrate 1850} & 0.00169 & & & \\
\hline & $(0.00216)$ & & & \\
\hline \multirow[t]{2}{*}{ Urbrate $1800-1900$} & & 0.0007 & & \\
\hline & & $(0.001)$ & & \\
\hline \multirow[t]{2}{*}{ Urbrate $1700-1800$} & & & 0.0003 & \\
\hline & & & $(0.004)$ & \\
\hline \multirow[t]{2}{*}{ Share of Protestants 1800} & & & & 0.0071 \\
\hline & & & & $(0.092)$ \\
\hline$N$ & 4031 & 4031 & 4031 & 4031 \\
\hline$R^{2}$ & 0.071 & 0.071 & 0.071 & 0.071 \\
\hline
\end{tabular}

Notes: OLS regressions. Dependent variables: Trust is the average of answers given to the following questions: "On the whole one cannot trust people", "Nowadays one can't rely on anyone" "If one is dealing with strangers, it is better to be careful before one can trust them". Source: German SocioEconomic Panel, wave 2003.

Heteroscedastic-robust standard errors in parentheses. ${ }^{*} p<0.10,{ }^{* *} p<0.05,{ }^{* * *} p<0.01$ 


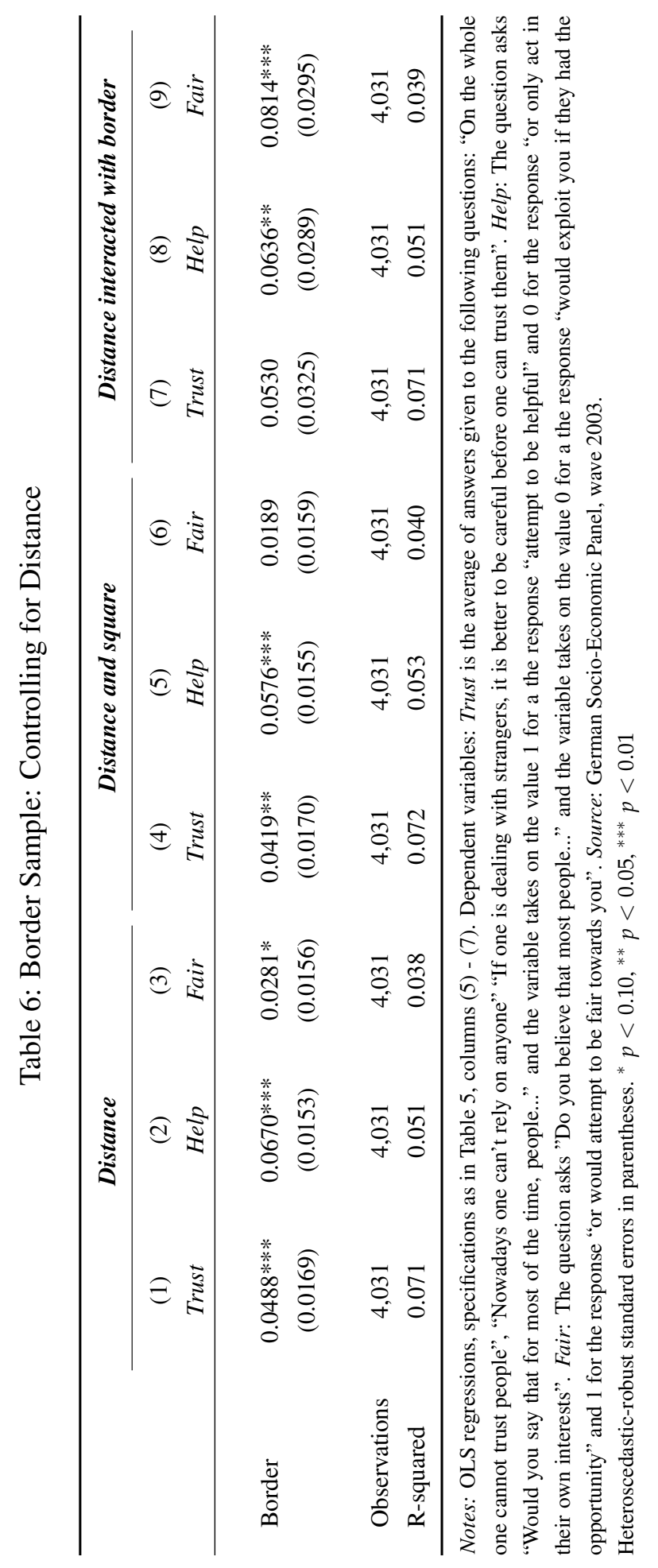


Table 7: Moving the Border

\begin{tabular}{|c|c|c|c|c|c|c|c|c|}
\hline & \multicolumn{4}{|c|}{ Moving border outwards } & \multicolumn{4}{|c|}{ Moving border inwards } \\
\hline & (1) & (2) & (3) & (4) & (5) & (6) & (7) & (8) \\
\hline & Trust & Trust & Trust & Trust & Trust & Trust & Trust & Trust \\
\hline \multirow[t]{2}{*}{ Border Outwards } & 0.0219 & 0.00504 & -0.00646 & -0.00248 & & & & \\
\hline & $(0.0195)$ & $(0.0228)$ & $(0.0222)$ & $(0.0228)$ & & & & \\
\hline \multirow[t]{2}{*}{ Border Inwards } & & & & & -0.0135 & -0.0110 & -0.0278 & -0.00182 \\
\hline & & & & & $(0.0292)$ & $(0.0294)$ & $(0.0291)$ & $(0.0292)$ \\
\hline Individual Controls & Yes & Yes & Yes & Yes & Yes & Yes & Yes & Yes \\
\hline Religion (4 categories) & No & No & Yes & Yes & No & No & Yes & Yes \\
\hline Education ( 5 categories) & No & No & Yes & Yes & No & No & Yes & Yes \\
\hline Economic Controls & No & No & Yes & Yes & No & No & Yes & Yes \\
\hline Urbrate 1850 & No & No & No & Yes & No & No & No & Yes \\
\hline Fed. State FE & No & Yes & Yes & Yes & No & Yes & Yes & Yes \\
\hline Observations & 3,265 & 3,265 & 3,265 & 3,265 & 2,307 & 2,307 & 2,307 & 2,307 \\
\hline R-squared & 0.001 & 0.008 & 0.076 & 0.076 & 0.008 & 0.008 & 0.065 & 0.074 \\
\hline
\end{tabular}

Notes: OLS regressions. Dependent variables: Trust is the average of answers given to the following questions: "On the whole one cannot trust people", "Nowadays one can't rely on anyone" "If one is dealing with strangers, it is better to be careful before one can trust them". Source: German Socio-Economic Panel, wave 2003.

Historical Controls include the share of protestants and the rate of urbanization in 1800 .

Heteroscedastic-robust standard errors in parentheses. ${ }^{*} p<0.10,{ }^{* *} p<0.05,{ }^{* * *} p<0.01$ 
Table 8: Pre-Treatment Mean Comparisons

\begin{tabular}{|c|c|c|c|c|}
\hline & \multicolumn{2}{|c|}{ Complete Sample } & \multicolumn{2}{|c|}{ Territories in Border Sample } \\
\hline & Mean diff. & t-stat. & Mean diff. & t-stat. \\
\hline \multicolumn{5}{|l|}{ Territory level } \\
\hline Years French Presence & $6.750^{*}$ & $(2.04)$ & 9.667 & $(1.14)$ \\
\hline Distance to Paris & -113.1 & $(-1.26)$ & $-71.23^{* *}$ & $(-5.19)$ \\
\hline No of Territories & 14.17 & $(1.65)$ & -4.667 & $(-0.35)$ \\
\hline Latitude & -1.655 & $(-1.69)$ & -0.813 & $(-0.63)$ \\
\hline Longitude & -0.481 & $(-0.42)$ & -0.265 & $(-0.39)$ \\
\hline Urbrate 1800 & -0.0447 & $(-0.01)$ & 1.827 & $(0.48)$ \\
\hline Urbrate $1700-1800$ & -0.704 & $(-0.22)$ & 1.261 & $(0.35)$ \\
\hline Population $1700-1800$ & 320669.0 & $(1.33)$ & 87651.4 & $(0.16)$ \\
\hline Share of protestants 1800 & -0.237 & $(-1.36)$ & -0.183 & $(-1.12)$ \\
\hline Observations & 17 & & 5 & \\
\hline \multicolumn{5}{|l|}{ City level } \\
\hline Free cities & 0.0288 & $(0.75)$ & 0.0644 & $(1.04)$ \\
\hline Free cities (weight pop). & 0.186 & $(0.01)$ & 11.64 & $(0.68)$ \\
\hline Hansa Cities & $-0.295^{* * *}$ & $(-5.90)$ & $-0.390^{* * *}$ & $(-5.32)$ \\
\hline Hansa Cities (weight pop) & -23.85 & $(-1.53)$ & -16.76 & $(-0.85)$ \\
\hline Bishop Cities & -0.0417 & $(-1.33)$ & 0.0417 & $(1.15)$ \\
\hline Bishop Cities (weight pop) & -4.641 & $(-0.36)$ & 17.65 & $(1.24)$ \\
\hline Universities & -0.0248 & $(-0.75)$ & 0 & $(0.00)$ \\
\hline Observations & 364 & & 154 & \\
\hline
\end{tabular}

Notes: This table reports mean comparisons of several variables measured at the territory level (upper panel) and the city level (lower panel). Treatment is defined to be equal to 1 for the territories Baden, Bavarian Palatinate, Rhineland and Saxony in the complete sample and Baden, Bavarian Palatinate and Rhineland in the border sample. Columns (2) and (4) report mean differences, defined as the difference between the mean of a variable for the treated group subtracted by the mean of the same variable for the untreated group. $t$ statistics in parentheses. ${ }^{*} p<0.10,{ }^{* *} p<0.05,{ }^{* * *} p<0.01$. 
Table 9: Summary Statistics: Historical Data

\begin{tabular}{|c|c|c|c|c|c|}
\hline & Mean & Std. Dev. & Min. & Max. & $N$ \\
\hline \multicolumn{6}{|l|}{ Employment Shares } \\
\hline Tade & 0.009 & 0.005 & 0.001 & 0.034 & 323 \\
\hline Factory & 0.032 & 0.055 & 0.001 & 0.488 & 323 \\
\hline Craft & 0.198 & 0.1 & 0.041 & 0.872 & 323 \\
\hline $\mathrm{TrFaCr}$ & 0.094 & 0.071 & 0.015 & 0.559 & 323 \\
\hline Civil & .0001 & .0002 & 0 & 0.003 & 324 \\
\hline Servants & 0.009 & 0.009 & 0 & 0.084 & 324 \\
\hline \multicolumn{6}{|c|}{ Other Regional Characteristics } \\
\hline Share of Protestants & 0.595 & 0.388 & 0.002 & 0.997 & 324 \\
\hline Share of Jews & 0.011 & 0.013 & 0 & 0.082 & 324 \\
\hline Share of Female Population & 0.503 & 0.011 & 0.465 & 0.526 & 324 \\
\hline Total Population (ln) & 10.842 & 0.375 & 9.582 & 12.388 & 324 \\
\hline Income & 0.594 & 0.41 & 0.052 & 3.805 & 324 \\
\hline Elementary Schools p.c. & 0.001 & .0005 & .0004 & 0.003 & 324 \\
\hline Longitude & 8.221 & 26.442 & -159.393 & 141.95 & 324 \\
\hline Latitude & 50.492 & 7.065 & -16.162 & 77.383 & 324 \\
\hline \multicolumn{6}{|l|}{ Gymnast Clubs and Firemen } \\
\hline Firemen p.c. (x100) & 0.04 & 0.08 & 0 & 0.7 & 234 \\
\hline Member p.c. (x100) & 0.3 & 0.21 & 0.0041 & 1.2 & 234 \\
\hline Member & 176.90 & 187.2 & 4 & 1761 & 234 \\
\hline Firemen & 25.24 & 51.41 & 0 & 358 & 234 \\
\hline
\end{tabular}




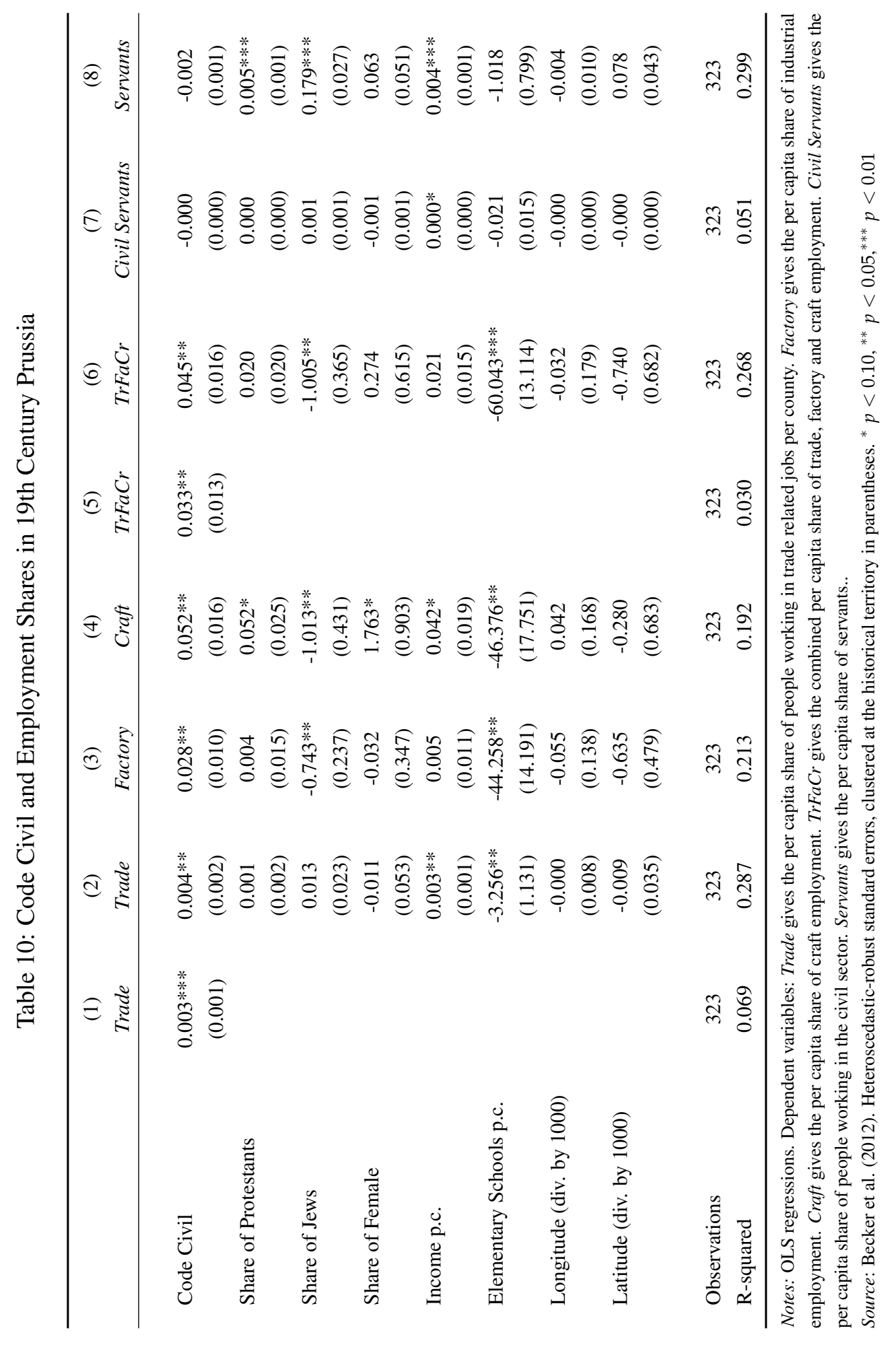


Table 11: Code Civil and 19th Century Associational Participation

\begin{tabular}{|c|c|c|c|c|c|c|}
\hline & $\begin{array}{c}(1) \\
\text { Member p.c. } \\
(x 100)\end{array}$ & $\begin{array}{c}(2) \\
\text { Firemen p.c. } \\
(x 100)\end{array}$ & $\begin{array}{c}(3) \\
\text { Firemen }\end{array}$ & $\begin{array}{c}\text { (4) } \\
\text { Member }\end{array}$ & $\begin{array}{c}(5) \\
\text { Member p.c. } \\
(x 100)\end{array}$ & $\begin{array}{c}(6) \\
\text { Firemen p.c. } \\
(x 100)\end{array}$ \\
\hline Code Civil & $\begin{array}{c}0.109 * * * \\
(0.032)\end{array}$ & $\begin{array}{l}0.008^{*} \\
(0.004)\end{array}$ & $\begin{array}{c}15.089 * * * \\
(3.725)\end{array}$ & $\begin{array}{c}125.874 * * * \\
(30.759)\end{array}$ & $\begin{array}{c}0.077 * \\
(0.038)\end{array}$ & $\begin{array}{l}0.012 * \\
(0.006)\end{array}$ \\
\hline Share of Protestants & $\begin{array}{c}0.250 * * * \\
(0.043)\end{array}$ & $\begin{array}{c}0.035 * * \\
(0.013)\end{array}$ & $\begin{array}{c}20.468 * \\
(9.693)\end{array}$ & $\begin{array}{c}170.604 * * * \\
(47.019)\end{array}$ & $\begin{array}{c}0.302^{* * *} \\
(0.040)\end{array}$ & $\begin{array}{c}0.054 * * \\
(0.016)\end{array}$ \\
\hline Income p.c & $\begin{array}{c}0.052 \\
(0.038)\end{array}$ & $\begin{array}{c}0.012 \\
(0.008)\end{array}$ & $\begin{array}{c}4.913 \\
(5.936)\end{array}$ & $\begin{array}{c}18.252 \\
(25.998)\end{array}$ & $\begin{array}{c}0.018 \\
(0.041)\end{array}$ & $\begin{array}{l}-0.002 \\
(0.011)\end{array}$ \\
\hline Longitude (div. by 1000) & $\begin{array}{c}0.346 \\
(0.467)\end{array}$ & $\begin{array}{c}0.071 \\
(0.083)\end{array}$ & $\begin{array}{c}10.721 \\
(78.955)\end{array}$ & $\begin{array}{c}106.705 \\
(341.337)\end{array}$ & $\begin{array}{c}0.410 \\
(0.432)\end{array}$ & $\begin{array}{c}0.036 \\
(0.092)\end{array}$ \\
\hline Latitude (div. by 1000) & $\begin{array}{l}-0.742 \\
(1.502)\end{array}$ & $\begin{array}{c}0.201 \\
(0.485)\end{array}$ & $\begin{array}{c}-83.788 \\
(265.255)\end{array}$ & $\begin{array}{l}-758.603 \\
(584.881)\end{array}$ & $\begin{array}{l}-1.055 \\
(1.382)\end{array}$ & $\begin{array}{c}0.288 \\
(0.493)\end{array}$ \\
\hline Elementary Schools p.c. & & & & & $\begin{array}{c}-111.155^{* * *} \\
(20.023)\end{array}$ & $\begin{array}{c}-49.619 * * \\
(15.035)\end{array}$ \\
\hline Share of Female & & & & & $\begin{array}{c}-3.306^{* *} \\
(1.085)\end{array}$ & $\begin{array}{c}0.312 \\
(0.335)\end{array}$ \\
\hline ln Population & & & $\begin{array}{c}40.508 \\
(21.943)\end{array}$ & $\begin{array}{c}257.183 * * * \\
(74.419)\end{array}$ & & \\
\hline Observations & 234 & 234 & 234 & 234 & 234 & 234 \\
\hline R-squared & 0.156 & 0.024 & 0.106 & 0.346 & 0.234 & 0.080 \\
\hline
\end{tabular}

Notes: OLS regressions. Dependent variables: Member p.c. gives the per capita share of members in gymnast clubs (multiplied by 100). Firemen p.c. gives the per capita share of voluntary firemen per county (multiplied by 100). Member gives the total number members in gymnast clubs. Firemen gives the total number volunteer firemen per county.

Source: Second Statistical Yearbook of Germany Gymnast Clubs, (Hirth, 1865). Heteroscedastic-robust standard errors, clustered at the historical territory in parentheses. ${ }^{*} p<0.10,{ }^{* *} p<0.05,{ }^{* * *} p<0.01$ 


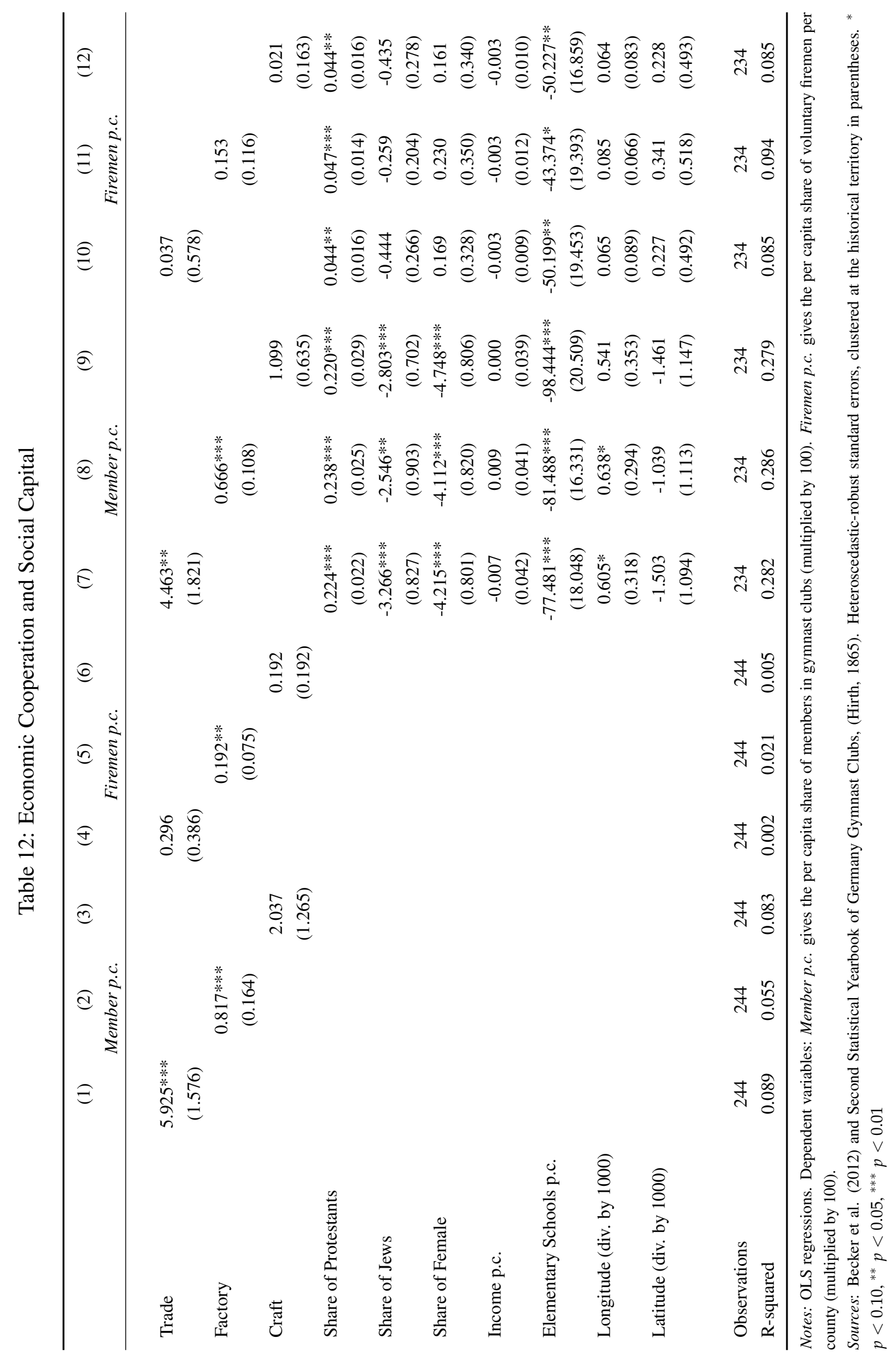


Table 13: Shooting Clubs

(1)

No. of Clubs founded

$1700-1750$

$1750-1800$

$1800-1850$

$1850-1900$

Panel A
Code Civil

$-0.147$

(0.284)

$(0.221)$

$(0.221)$

Panel B

Code Civil

Lagged No Clubs

Observations

$-2.782 * * *$

(0.873)

$.954^{*}$

(1.142)

$\begin{array}{ccc}-0.434 * * & -2.055 * * * & 3.361 * * * \\ (0.181) & (0.722) & (1.070) \\ 0.447 * * * & 1.124 * * * & 0.410 * * * \\ (0.057) & (0.142) & (0.078)\end{array}$

128

128

128

Notes: OLS regressions. Dependent variable are the number of clubs founded per district. Code Civil equals 1 for districts belonging to the province Rhineland, and 0 for districts belonging to Westphalia.

Source: Plett, W. (1991). Standard errors in parentheses. ${ }^{*} p<0.10,{ }^{* *} p<0.05,{ }^{* * *} p<0.01$ 


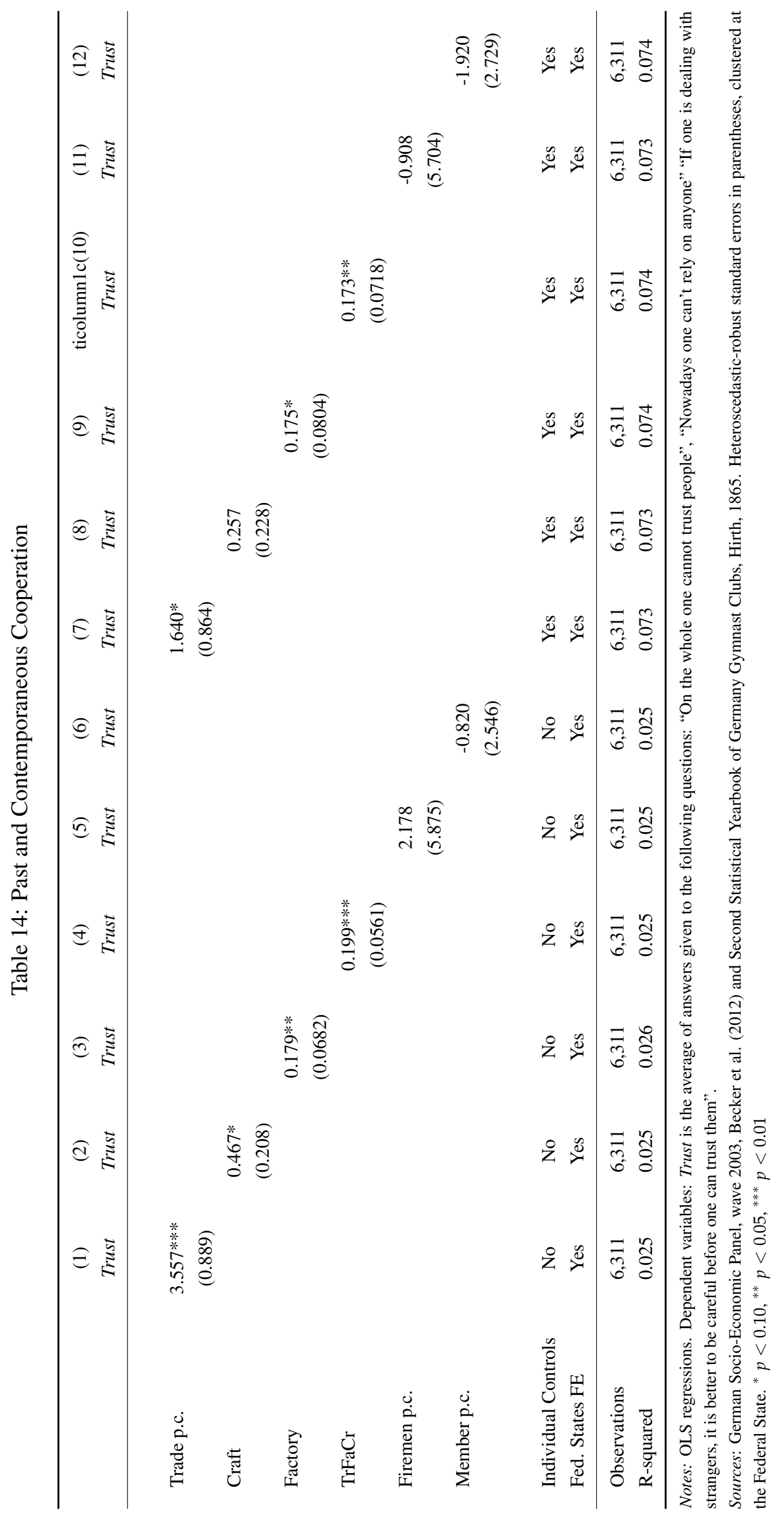




\section{B FIGURES}

Figure 1: Legal Quality and Trust across Countries

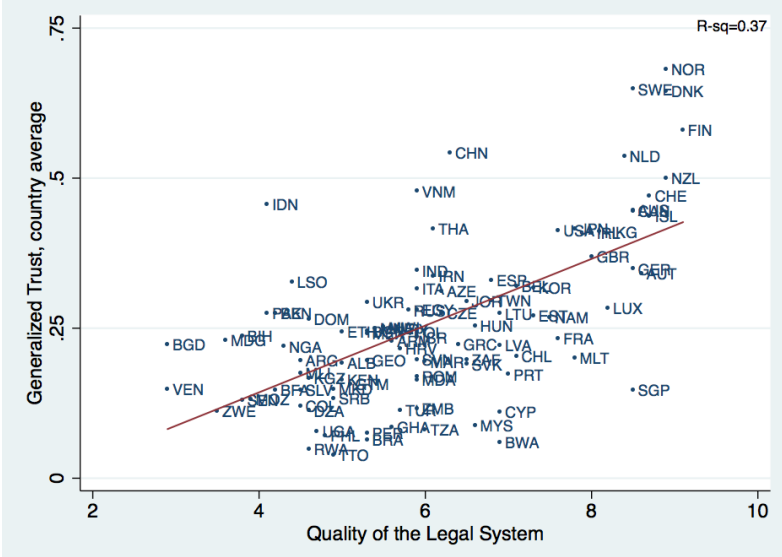

Notes: This figure shows the cross-country correlation between generalized trust and the composite index of the legal system. Sources: World Values Survey, Economic Freedom of the World Index 2010.

Figure 2: Legal Quality and Trust across Countries: Adding Controls

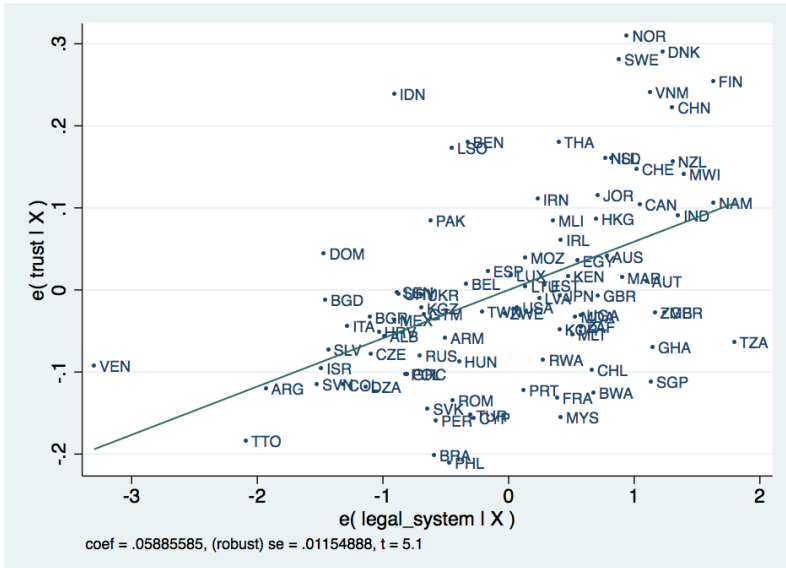

Notes: This figure shows the cross-country correlation between generalized trust and the composite index of the legal system, controlling for population, per capita income, education and ethnic fractionalization. Sources: World Values Survey, Economic Freedom of the World Index 2010 
Figure 3: Distribution of Law in 19th Century German

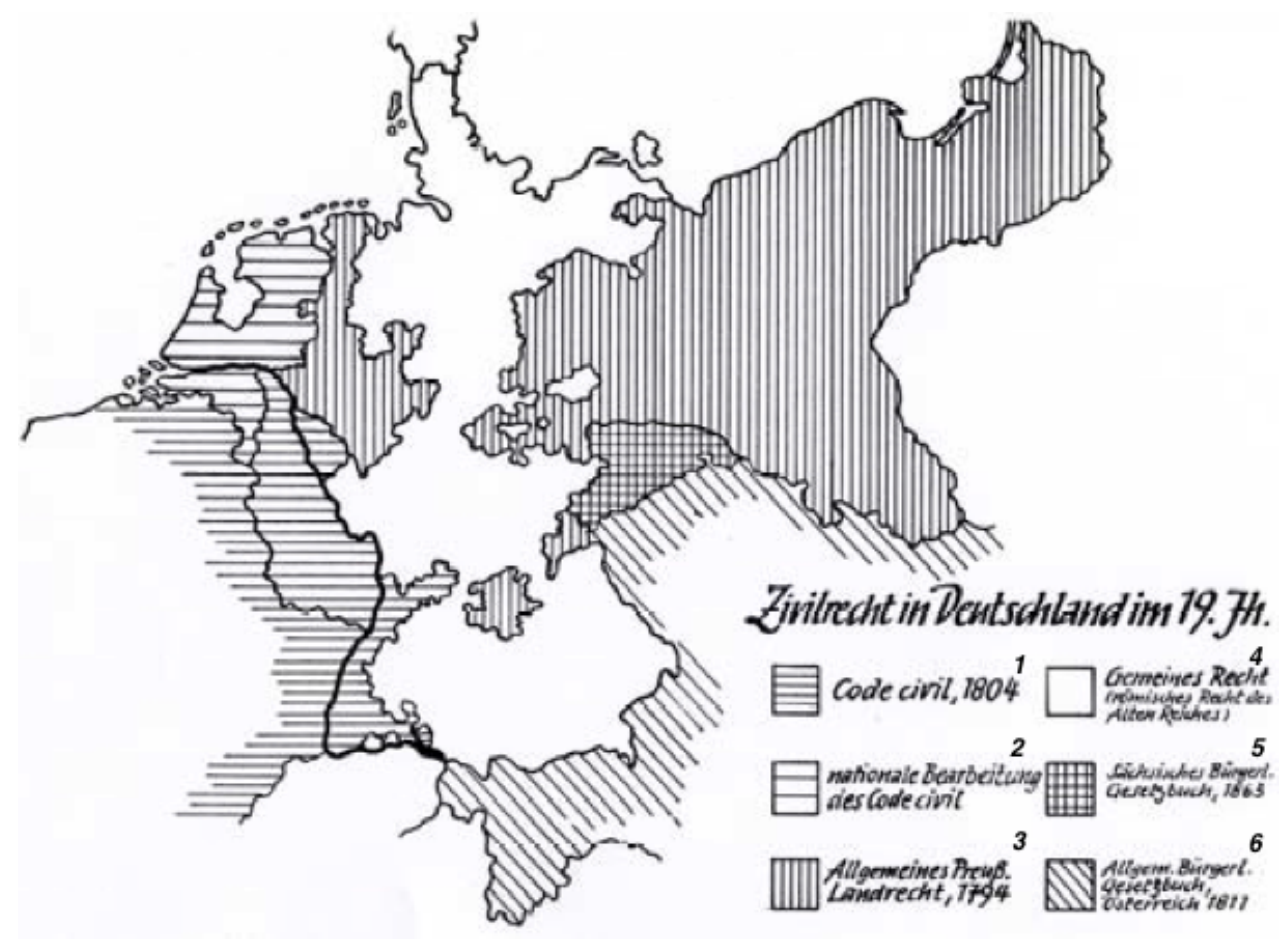

Notes: This figure displays civil law in 19th century Germany. Translation of the legend: Civil Law in Germany in the 19th century (heading). 1) Code Civil, 1804. 2) National modification of the Code Civil. 3) ALR, 1794. 4) Common Law (roman Law of the Holy Roman Empire). 5) Saxonian Civil Code, 1865. 6) Austrian Civil Code, 1811.

Source: 200 years Code Civil: Exposition in the federal archiv, Koblenz. In: Stein (2004). 
Figure 4: Treatment in the Complete Sample

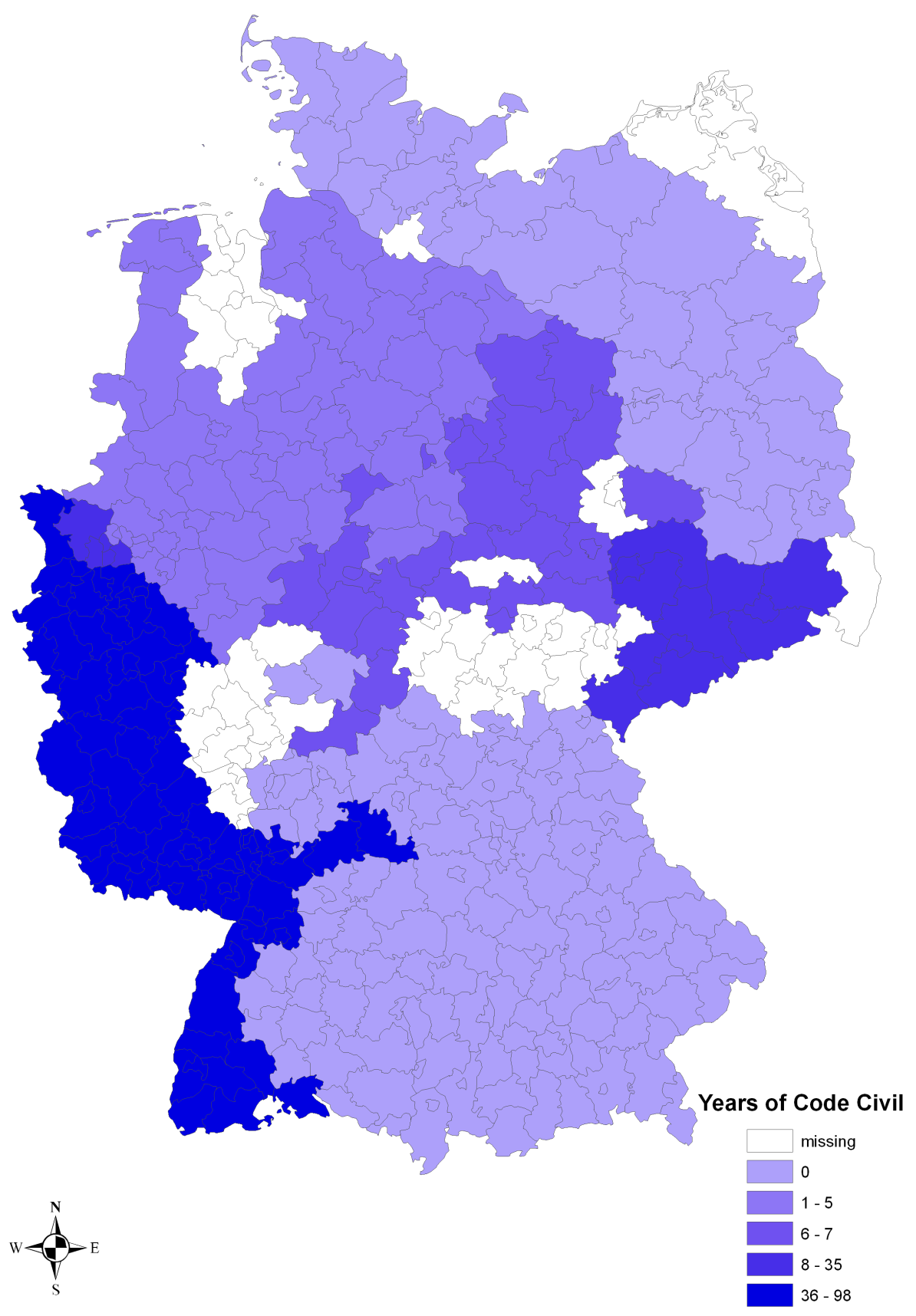

Notes: This figure shows the distribution of the number of years the Code Civil was in place in German Regions. White areas represent historical territories not included in the sample. 
Figure 5: Border Treatment

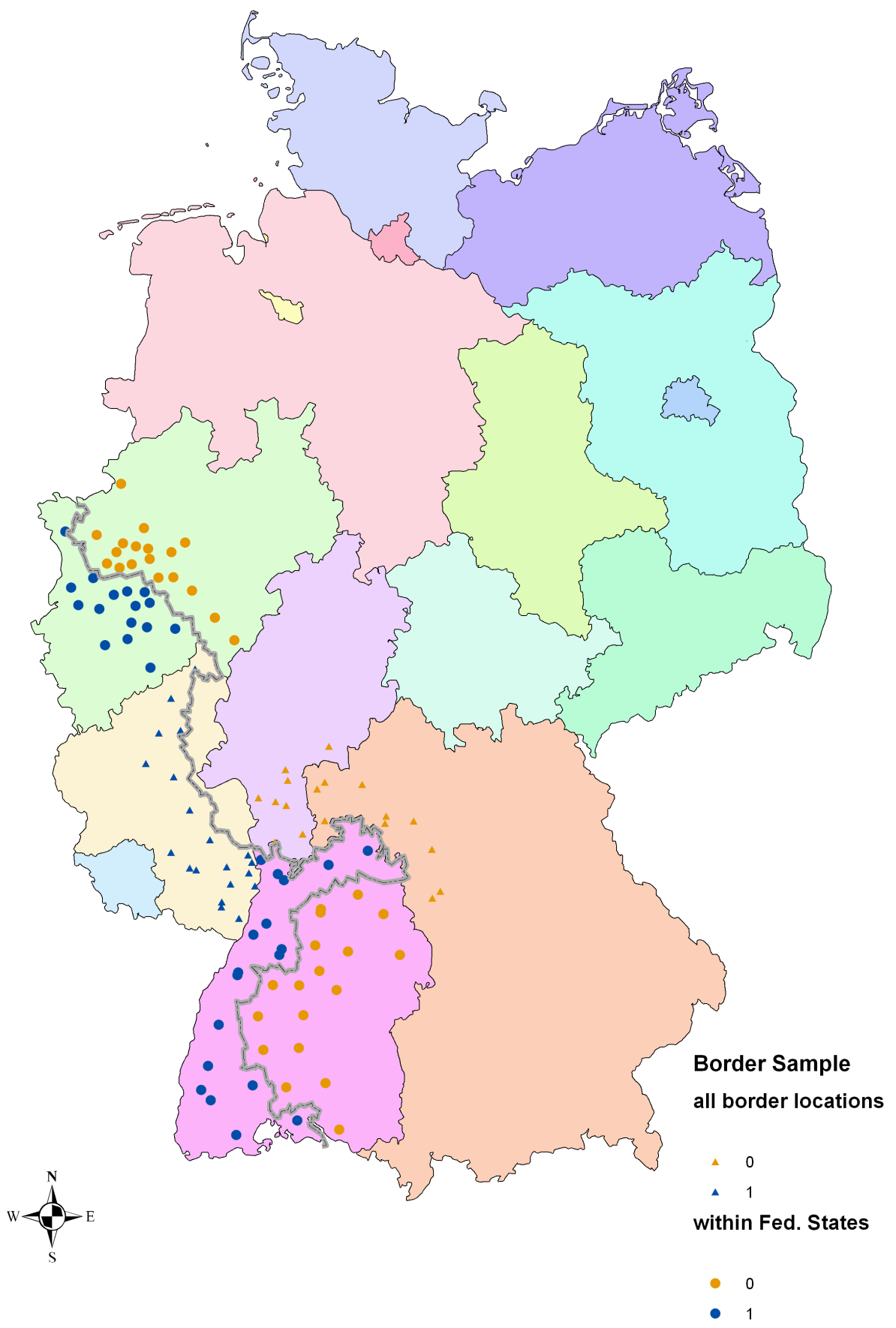

Notes: This figure shows the centroids of the counties included in the Border Sample with a maximal distance of $50 \mathrm{~km}$ to the borderline drawn in grey. Blue (dark) circles represent the treated, yellow (bright) circles the control group. Triangles represent the centroids of additional counties which are located in Federal States (colored areas) without within-State variation. 
Figure 6: Border Movement

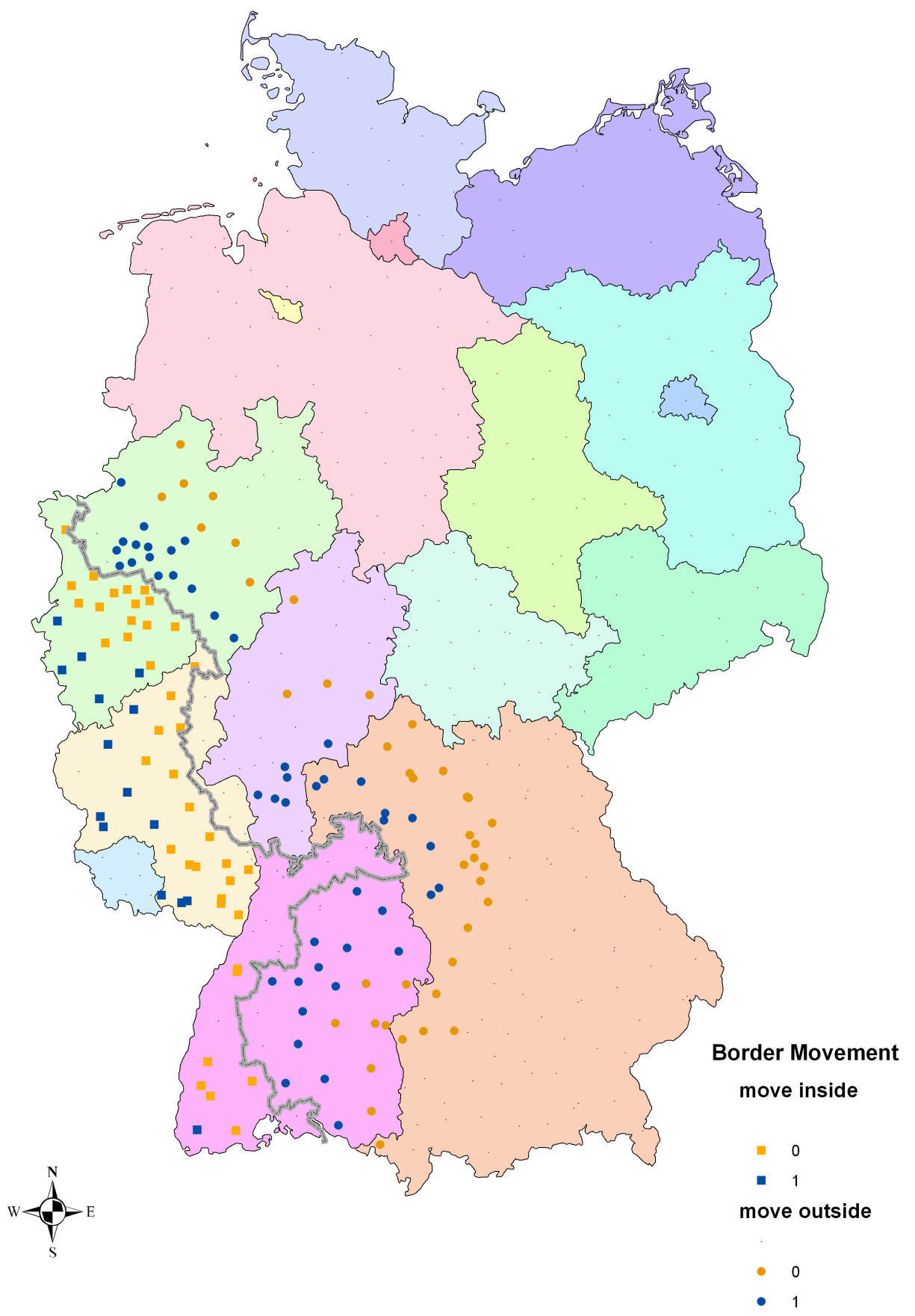

Notes: This figure shows the centroids of the counties included in the sample when the border is moved and the original borderline in grey. Squares indicate counties included in the sample when the border is moved inwards. Points indicate regions included in the sample when the border is moved outwards. Treatment is defined as being on the left of the respective border, i.e. for the blue (dark) squares/points. 